Copyright (C) 2021 by Cherkas Global University

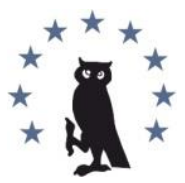

Published in the USA

Voennyi Sbornik

Has been issued since 1858 .

E-ISSN: $2409-1707$

2021. 9(2): $76-99$

DOI: $10.13187 / v s .2021 .2 .76$

https://vs.cherkasgu.press

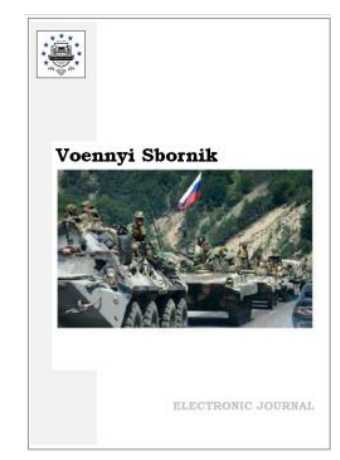

\title{
Creation and Combat Operations of Fighter-Sabotage Detachments of the Black Sea Group of Troops during the Second World War
}

Konstantin V. Taran a, b, *

a Cherkas Global University, Washington, USA

b Volgograd State University, Volgograd, Russian Federation

\begin{abstract}
This article discusses the creation and combat operations of fighter-sabotage detachments of the Black sea group of troops of the Transcaucasian Front, the purpose of which was the destruction of manpower and equipment of the troops of the Hitlerite coalition. Besides this, acting in the rear of the troops of the Third Reich, the fighter-sabotage detachments extracted valuable intelligence data.

The materials from the Central archive of the Ministry of Defense of the Russian Federation (Podolsk, Russian Federation) were used as sources, such as final operational reports, combat logs, combat reports, certificates, reports, reports, etc. In addition, the collections of archival documents and materials, as well as research by soviet, russian and foreign authors were involved.

In conclusion, the author points out that as a result of the fighting of the fighter-sabotage detachments, the significant losses of manpower and equipment were inflicted on the troops of the Third Reich, as well as valuable intelligence documents were seized.

Keywords: World War II, North Caucasian Front, fighter-sabotage detachments, Black Sea group of troops, Transcaucasian Front.

\section{1. Введение}

Созданию истребительно-диверсионных отрядов Черноморской группы войск предшествовало стремительное наступление войск вермахта, начавшееся 25 июля 1942 г. в южном направлении. Немецкое командование планировало захватить нефтедобывающие районы советского Кавказа, обеспечить войска гитлеровской коалиции горючим для боевой техники и, соответственно, лишить такой возможности части и соединения РККА 1 .

В данной статье рассматриваются создание и боевая деятельность истребительнодиверсионных отрядов Черноморской группы войск Закавказского фронта в тылу войск гитлеровской коалиции, благодаря которым войскам Третьего рейха был нанесен значительный ущерб в живой силе и технике.
\end{abstract}

\section{2. Материалы и методы}

В качестве материалов применялся комплекс разнообразных источников. В первую очередь были использованы источники Центрального архива Министерства обороны Российской Федерации (Подольск, Российская Федерация), воспоминания советских

\footnotetext{
* Corresponding author

E-mail addresses: taran.constantin@yandex.ru (K.V. Taran)

${ }^{1}$ РККА - Рабоче-крестьянская Красная армия
} 
военачальников, сборники архивных документов, справочная литература, а также монографии, статьи и публикации советских, российских и зарубежных авторов.

Методологической основой работы выступили как специальные исторические, так и общенаучные методы исследования. В качестве специальных традиционных исторических методов в основном применялся историко-генетический, иллюстрирующий причинноследственные связи между действиями персоналий и наступившими вследствие этого событиями, а также объясняющий происхождение тех или иных процессов. Использовался и историко-сравнительный метод, в частности сравнение сил дислоцированных в районе боевых действий частей вермахта и РККА.

Историко-системный метод позволил провести анализ в неотрывной связи с существовавшей в указанный хронологический период исследования военной, географической, климатической, социальной и экономической обстановкой и др.

Применялся также нетрадиционный для исторической науки историкостатистический (количественный/математический) метод (статистический анализ численности личного состава, вооружения сторон и пр.). Кроме того, использовались общенаучные методы исследования, такие как синтез, анализ, обобщения, классификации и категоризации.

В основе исследования лежит принцип историзма, который позволил сделать комплексный объективный анализ архивных материалов и иных источников, относящихся к созданию и боевой деятельности истребительно-диверсионных отрядов Черноморской группы войск Закавказского фронта.

\section{3. Обсуждение}

Тема создания и боевые действия истребительно-диверсионных отрядов Черноморской группы войск Закавказского фронта была частично рассмотрена исследователем И.В. Киселевым (Киселев, 2020: 126-129), который в своей работе отразил создание отрядов и их боевую деятельность в ноябре 1942 г. Кроме этого, определенный интерес вызывает освещение исследователем (Киселев, 2017b) боевой деятельности разведывательных диверсионных групп Черноморской группы войск.

Тема боевой деятельности истребительно-диверсионных отрядов нами была частично затронута при исследовании боевых действий на Лазаревском направлении в октябредекабре 1942 г. (Taran, 2021a: 62).

В своих мемуарах Леон Дегрелль (Дегрелль, 2013) дает характеристику боевой деятельности истребительно-диверсионных отрядов, ошибочно полагая, что систематический урон в живой силе войскам вермахта наносили партизанские отряды.

\section{4. Результаты}

В середине августа 1942 г. немецкая группа армий «Юг» (командующий фельдмаршал Лист) из района Ростов-на-Дону, оторвавшись от своих баз, не обращая внимания на коммуникации и не закрепляясь на занятых рубежах, продолжала теснить части и соединения Северо-Кавказского фронта к перевалам Главного Кавказского хребта. На отдельных участках, пользуясь слабым сопротивлением войск РККА, немцы проникали в тыл советских частей и соединений. При этом отдельные части и соединения СевероКавказского фронта, действовавшие на территории Краснодарского края, вместо активного сопротивления и нанесения войскам гитлеровской коалиции поражений, отходили на юг. В сложившейся обстановке для устранения указанных недочетов, перехода от пассивного отхода к активной обороне 16 августа 1942 г. командующий Северо-Кавказским фронтом маршал Советского Союза С.М. Буденный издал приказ № 0695/ОП. Этот приказ обязывал командующих 47, 56, 12, 18 армиями и командира 17 кавалерийского корпуса, выполняя приказ Сталина № 227, прочно закрепиться на оборонительных рубежах, используя благоприятные условия горно-лесистой местности. Активными действиями в обороне и партизанской борьбой воинских частей в тылу войск вермахта наносить им удары по коммуникациям и живой силе. Для обеспечения питанием отрядов рекомендовалось использовать местные ресурсы, 
а в качестве проводников использовать местных жителей, проверив их через органы НКВД² (ЦАМО. Ф. 276. ОП. 811. Д. 21. Л. 14-15).

Кроме этого, в приказе Буденный обращал внимание на то, что в горах немецкие войска теряют основное превосходство в моторизованных частях, а леса укрывают красноармейцев от авиации противника; поэтому, если части вермахта глубоко прорывались в ущелья, не отходить, а, сковывая противника с фронта незначительными силами на наиболее удобных рубежах, ударом главных сил во фланг и тыл окружать и уничтожать живую силу германских войск в долинах горных рек, ущельях. С этой же целью перерезать коммуникации, уничтожать базирование, широко практиковать обвалы, обрушение троп и скал. За дальнейший прорыв немецких войск на отдельных направлениях и узлах, отказ от борьбы на занимаемых рубежах Буденный обещал снимать командный состав с занимаемых должностей и предавать суду Военного трибунала; также он потребовал от командующих армиями представить планы активной обороны на утверждение 18 августа 1942 г., а приказ № 0695/ОП объявить всему командному составу и разъяснить красноармейцам (ЦАМО. Ф. 276. Оп. 811. Д. 21. Л. 15).

На приказ командующего фронтом на следующий день отреагировало командование 56 армией: ее командующий генерал-майор Рыжов, член Военного совета бригадный комиссар Комаров, полковой комиссар Кальченко и начальник штаба 56 армии генералмайор Иванов в директиве командирам частей и соединений армии от 17 августа 1942 г. предлагали осмыслить новые тактические решения для ведения боевых действий в горнолесистой местности (ЦАМО. Ф. 276. ОП. 811. Д. 19. Л. 54).

Учитывая сложившуюся обстановку на фронте, командование 56 армией обращало внимание командиров дивизий и бригад на то, что боевые действия предстояло вести в горно-лесистой местности и в новых климатических условиях. Следовало учитывать пересеченную местность, которая требовала от войск большего физического напряжения, а также отсутствие населения и местных ресурсов. В наличии имелось незначительное число путей сообщения, годных для колесного транспорта, небольшое количество поперечных (рокадных) дорог, затрудняющих маневр и рокировку войск. Боевые действия в горах за овладение хребтами, горными проходами и узлами дорог предлагалось вести самостоятельными подразделениями, частями, соединениями, состоящими из разных родов войск, действующих изолированно друг от друга. Решающее значение в горно-лесистой местности приобретали инициатива командного состава, дисциплина, стойкость, мужество, решительность и дерзость (ЦАМО. Ф. 276. Оп. 811. Д. 19. Л. 54).

Командование 56 армией полагало, что бои в горно-лесистой местности должны вестись всеми родами войск, но наиболее эффективным считали использование пехоты. Предлагалось в частях и соединениях создавать и готовить отряды, которые должны были хорошо изучить местность. Кроме того, вооружить эти отряды автоматами, гранатами с задачами выходить смело и решительно на фланги и в тыл наступающим немецким частям с целью физического уничтожения противника. Практиковать в немецком тылу засады из смельчаков, отважных, самоотверженных бойцов и командиров, чтобы внезапным нападением наносить войскам Третьего рейха большие потери (ЦАМО. Ф. 276. Оп. 811. Д. 19. Л. 55).

Штаб Северо-Кавказского фронта 19 августа в оперативной директиве № 381/ОП в целях прочной обороны перевалов Главного Кавказского хребта и надежного прикрытия направлений на Лазаревское, Туапсе и Новороссийск приказал командующим армиями, командирам корпусов и дивизий оборону сделать активной. Необходимо было широко применять небольшие истребительные отряды для действий на коммуникациях немецких войск с целью внезапных и коротких ударов в тылу и по флангам германской группировки (ЦАМО. Ф. 276. ОП. 811. Д. 231. Л. 19).

После анализа приказа и директив, где рассматривались боевые действия отдельных войсковых частей, смельчаков и истребительных отрядов в тылу войск гитлеровской коалиции, штабом Северо-Кавказского фронта 20 августа 1942 г. был издан приказ № 0711/ОП о создании истребительно-диверсионных отрядов, основная деятельность которых должна быть направлена на удары по коммуникациям войск вермахта и нанесение внезапных коротких ударов в немецком тылу (ЦАМО. Ф. 3470. Оп. 1. Д. 12. Л. 230).

2 НКВД - Народный комиссариат внутренних дел. 
В соответствии с приказом необходимо было в армиях создать не менее 4-5 истребительно-диверсионных отрядов. Создание, руководство и организация боевой деятельности отрядов возлагались на начальников штабов армий, которым они непосредственно и подчинялись. Во главе отряда необходимо было назначать боевого опытного командира с волевыми качествами. Состав отряда подбирать за счет учебных и строевых подразделений из стойких, проверенных в бою красноармейцев и младших командиров, а также коммунистов и комсомольцев. Отряд должен был состоять из 25 человек, из которых 10 автоматчиков, 2 бойца с противотанковыми ружьями, 3-5 саперов и один радист с радиостанцией батальонной или рацией «Север». Для выполнения боевой задачи отряду выделялся боевой запас в пределах 3-4 боекомплектов и 5-6 гранат на бойца, соответствующее количество зажигательных бутылок и взрывчатых веществ, а также довольствие в виде концентратов. Предлагалось по возможности использовать местные ресурсы. Каждому отряду выделялся определенный район действий или участок дороги в тылу немецких войск на расстоянии 30-50 км от линии фронта. Выход в тыл к району действия необходимо было прокладывать в горно-лесистой местности, при этом исключить движение отрядов по дорогам. Основная задача истребительно-диверсионных отрядов уничтожение живой силы, технических и материальных средств войск гитлеровской коалиции. Для ее выполнения отряд должен был произвести разведку в определенном ему районе, командиру отряда предоставлялась возможность самостоятельно решать поставленную задачу в соответствии с обстановкой. В качестве проводников следовало привлекать местных жителей, проверенных органами НКВД. Истребительно-диверсионные отряды необходимо было подготовить для выполнения поставленных задач и отправить за линию фронта к 1 сентября 1942 г., их формирование возлагалось на Военные советы армий. В качестве проверки деятельности отрядов после выполнения поставленных задач требовалась сдача захваченных документов и трофеев (ЦАМО. Ф. 3470. Оп. 1. Д. 12. Л. 230).

Получение приказа следовало подтвердить, исполнение донести, указав состав отрядов и поставленные задачи к 1 сентября 1942 г. Приказ подписали командующий СевероКавказским фронтом маршал Буденный, начальник штаба генерал-лейтенант Антонов и член Военного совета Каганович (ЦАМО. Ф. 3470. Оп. 1. Д. 12. Л. 231).

Создание истребительно-диверсионных отрядов в малочисленных частях и соединениях 18 армии (командующий генерал-лейтенант Ф.В. Камков) во второй половине августа 1942 г. не происходило, так как армия всеми силами сдерживала наступление 44 егерского корпуса войск вермахта в направлении Сочи - Лазаревское (Taran, 2020: 65-75).

После получения приказа № 0711/ОП незамедлительно отреагировали в штабе 12 армии - командующий генерал-майор А.А. Гречко, начальник штаба генерал-майор А.Г. Ермолаев, бригадный комиссар Я.В. Гольдштейн. Войскам армии 21 августа было отдано боевое распоряжение, которым предусматривалось для действий в тылу немецких войск создавать в дивизиях и бригадах по 3 истребительно-диверсионных отряда в количестве от 15 до 25 человек каждый, подчинявшихся непосредственно командирам дивизий и бригад (ЦАМО. Ф. 371. Оп. 6367. Д. 102. Л. 95).

В немецком тылу в районе Абхазской, Линейной и выс. 272.0 с 24 по 28 августа действовал армейский истребительно-диверсионный отряд 12 армии под командованием капитана В.А. Якушкина. В результате боевых действий было уничтожено до 50 человек войск вермахта, в том числе 1 майор и 1 старший лейтенант, а также 1 грузовая и 1 легковая автомашины, 1 кухня и 3 повозки. Был захвачен в плен 1 солдат 11 артиллерийского полка 1 моторизованной дивизии словаков. Взяты трофеи: 1 ручной пулемет, 6 винтовок, 1 бинокль и 50 гранат (ЦАМО. Ф. 371. Оп. 6367. Д. 102. Л. 102; там же Ф. 33. Оп. 682525. Д. 229. Л. 375-375об.).

Вечером 30 августа возвратился истребительно-диверсионный отряд 12 армии под командованием капитана Рутковского, действовавший в тылу войск Третьего рейха, который установил, что на участке фронта выс. 234.9, Лисицына Щель (4.8 км юговосточнее Ключевой), ввиду трудной проходимости леса действующих германских частей нет, этот участок немцами патрулировался перед передним краем советской обороны. Дороги от станицы Кутаисской на запад и северо-запад были вполне проходимыми для всех видов транспортов. Было отмечено движение машин и обозов немецких войск. Боевыми действиями отряда на этих дорогах уничтожено до 20 солдат и несколько подвод. Потери отряда: убито 2 человека и ранен 1 (ЦАМО. Ф. 371. Оп. 6367. Д. 102. Л. 105). 
В соответствии с приказом № 0711/ОП в 56 армии командованием 1173 стрелкового полка 349 стрелковой дивизии был создан из добровольцев истребительно-диверсионный отряд для засылки в тыл немецких войск. Группа в количестве 25 человек под командованием старшего лейтенанта Болдина, политрука Карнауха и заместителя политрука Седова 25 августа выбыла в северном направлении за линию фронта. Через несколько часов от группы была получена радиограмма: «Находимся в районе Горячий Ключ. Все в порядке» (ЦАМО. Ф. 276. Оп. 811. Д. 19. Л. 168). 26 августа группа возвратилась, захватив в плен немецкого мотоциклиста обер-ефрейтора Иосифа Ферка из 35 роты дивизиона противотанковой обороны 198 пехотной дивизии. Его задержание было произведено следующим образом: заместитель политрука Седов с четырьмя бойцами организовал засаду на дороге Горячий Ключ - Пензенская. Вскоре послышался шум приближающегося мотоцикла. Седов смело и неожиданно перегородил дорогу мотоциклисту, который выстрелами из пистолета ранил Седова в голову. Седов в ответ не стрелял, т.к. было необходимо взять немца живым и доставить в часть. Седов бросился немцу под ноги и повалил его на землю, а подоспевшие бойцы помогли Седову обезоружить немца и связать его. Кроме этого, были взяты трофеи: мотоцикл с коляской, противогаз, сумка с ракетами, пистолет, сумка с личными вещами и документами обер-ефрейтора (ЦАМО. Ф. 276. ОП. 811. Д. 19. Л. 169).

17 казачий кавалерийский корпус (командир генерал-майор Н.Я. Кириченко) 28 августа был преобразован в 4 гвардейский казачий кавалерийский корпус. В соединениях и частях корпуса истребительно-диверсионные отряды созданы не были. На участке обороны корпуса в районе Навагинской войска вермахта с 28 по 31 августа предприняли безуспешное наступление в направлении Туапсе (ЦАМО. Ф. 224. Оп. 760. Д. 59. Л. 124-134).

Части и соединения 47 армии (командующий генерал-майор Г.П. Котов) в течение августа 1942 г. отступали с Таманского полуострова и под натиском немецких войск 31 августа оставили Анапу. В период отступления советские войска несли ощутимые потери личного состава, поэтому в августе 1942 г. истребительно-диверсионные отряды в 47 армии не создавались (ЦАМО. Ф. 276. Оп. 811. Д. 59. Л. 510-5110б.).

В ходе трех августовских рейдов в тыл войск гитлеровской коалиции истребительнодиверсионными отрядами Северо-Кавказского фронта было уничтожено 70 солдат и офицеров войск вермахта, грузовая и легковая автомашины, 5 повозок и 1 кухня. Захвачено 2 пленных, 1 ручной пулемет, 6 винтовок, 1 бинокль, 50 гранат, 1 мотоцикл, 1 противогаз, 1 пистолет, сумка с ракетами, личные вещи и документы убитых. При этом отряды потеряли убитыми 2 человека и 2 раненых.

В соответствии с директивой Ставки Верховного Главнокомандования № 170596 от 1 сентября 1942 г. в целях удобства управления и улучшения снабжения войск СевероКавказский фронт преобразовывался в Черноморскую группу войск Закавказского фронта, командующим которой был назначен генерал-полковник Я.Т. Черевиченко. Объединение фронтов необходимо было закончить 4 сентября 1942 г. Маршал С.М. Буденный обязан был прибыть в Москву в распоряжение Ставки Верховного Главнокомандования (ЦАМО. Ф. 224. Оп. 760. Д. 59. Л. 138-1380б.).

В период с 1 по 9 сентября войска гитлеровской коалиции на Туапсинском и Лазаревском направлениях вели бои местного значения с переменным успехом. К 5 сентября войска вермахта овладели Таманским полуостровом, продолжили развивать наступление и 10 сентября овладели центральной и юго-восточной частью Новороссийска. Всего перед фронтом Черноморской группы войск на рубеже г. Матазык, Хадыженской, Северской, Абинской, Новороссийска установлено действие 15 дивизий войск Третьего рейха, из них две танковые, две мотодивизии, шесть пехотных, две горные, три кавалерийские (ЦАМО. Ф. 47. Оп. 1063. Д. 194. Л. 86).

В начале сентября, после приостановки наступления немецких войск в направлении Сочи - Лазаревское, активизировали свою боевую деятельность истребительнодиверсионные отряды, созданные в частях и соединениях 18 армии. Отряды действовали в немецком тылу в районах Самурской, Папоротного, Нефтегорска, Нефтяной, Хадыженского (ЦАМО. Ф. 276. ОП. 811. Д. 90. Л. 40б.).

В каждом стрелковом полку 383 стрелковой дивизии было создано по два отряда из добровольцев, а в артиллерийском полку - один. Первые боевые действия отрядов не 
давали должного эффекта, но уже после нескольких выходов в немецкий тыл и по мере накопления опыта и военной хитрости, приобретения навыков в ориентировке на горнолесистой местности результаты действий отрядов стали значительно эффективней.

Истребительно-диверсионный отряд № 1691 стрелкового полка 10 сентября произвел налет на обоз противника в районе станицы Кубано-Армянской, в результате которого убито 8 и до 15 солдат вермахта ранено, захвачено 4 винтовки, 1 ручной пулемет, 1 автомат, документы. Отряд отошел в лес после перехода в контратаку большой группы немецких автоматчиков из района Кубано-Армянской. Потери отряда: 3 человека пропало без вести (ЦАМО. Ф. 276. Оп. 811. Д. 7. Л. 75; там же Ф. 1704. Оп. 1. Д. 16. Л. 52).

14 сентября отряд № 2691 стрелкового полка произвел налет на обоз противника в районе западнее станицы Кубано-Армянской. Было уничтожил 12 подвод с боеприпасами и обмундированием, убито 15 и ранено до 30 немецких солдат. Захвачено: 1 ручной пулемет, 8 винтовок, 2 автомата, обмундирование. В тот же день отряд произвел налет на обоз войск гитлеровской коалиции в районе Озерова, в результате которого было убито 2 офицера, 9 солдат и до 20 солдат ранено. Захвачено: 1 ручной пулемет, 4 винтовки, 1 автомат и документы (ЦАМО. Ф. 276. ОП. 811. Д. 7. Л. 75).

Отряд № 1694 стрелкового полка, усиленный двумя противотанковыми ружьями, 6 сентября организовал засаду на дороге Нефтяная - Белая Глина, где были уничтожены бронемашина и гусеничный тягач с прицепом, груженный боеприпасами, и до 15 автоматчиков войск вермахта. Были захвачены 2 автомата, 1 радиостанция (снята с бронемашины), мешок с документами, патроны, гранаты, револьверы.

Истребительно-диверсионный отряд № 2694 стрелкового полка, усиленный противотанковым ружьем, действуя на дороге Нефтяная - Белая Глина, 7 сентября уничтожил 1 бронемашину и 1 автомашину, а 11 сентября в засаде у дороги Нефтяная Хадыженский - 2 мотоцикла и до 50 человек немецкой пехоты (ЦАМО. Ф. 276. Оп. 811. Д. 7. Л. 75).

В период с 6 по 9 сентября отряд № 1696 стрелкового полка в районе Суздальский, методом засад, уничтожил до 30 солдат вермахта и 1 грузовую машину с боеприпасами, захвачен 1 автомат.

Отряд № 2696 стрелкового полка с 7 по 9 сентября действовал в районе Травалева и также методом засады уничтожил 4 парные повозки с боеприпасами и хлебом, рассеял до 40 немецких автоматчиков, в числе которых убито и ранено до 25 человек (ЦАМО. Ф. 276. Оп. 811. Д. 7. Л. 75-76).

Истребительно-диверсионный отряд 696 артиллерийского полка произвел 9 сентября два налета на обозы и подразделения войск гитлеровской коалиции в районе восточнее 1 км Кубано-Армянской. Первый налет был на подводу с немецкими солдатами, в результате которого убито 3 солдата, второй - произведен на обоз из 40 подвод, сопровождавшийся 80 немецкими солдатами. В ходе боя убито 2 офицера, 30 солдат и ранено около 30 человек вермахта. Обоз был рассеян, захвачено обмундирование и документы убитых офицеров.

Два истребительно-диверсионных отряда 75 стрелкового полка 31 стрелковой дивизии высылались в немецкий тыл и действовали с 6 по 10 сентября в районе хутора Армянские. Каждый отряд состоял из 25 человек, вооруженных винтовками и автоматами. В районе хутора Армянские отряды вели бои с войсками вермахта, но успеха не имели, возвратились без результатов.

Истребительно-диверсионный отряд 509 стрелкового полка 236 стрелковой дивизии, действуя в районе Самурской, захватил одного пленного из 5 артиллерийского полка дивизии СС «Викинг» и принес очень ценные сведения об изменениях в группировке войск вермахта. Армейский истребительный отряд 236 стрелковой дивизии 6 сентября произвел два налета на немецкие обозы в районе дорог Поповский - Хадыженский и Суздальский - г. Лысая. Было уничтожено 5 офицеров, 61 солдат, захвачено 4 повозки с боеприпасами, один станковый пулемет, 2 противотанковых ружья, 3 миномета и 8 повозок (ЦАМО. Ф. 276. Оп. 811. Д. 7. Л. 76).

В результате боевых действий истребительно-диверсионных отрядов 18 армии в период с 1 по 15 сентября было уничтожено 9 офицеров, 231 солдат, 16 подвод с боеприпасами, 2 мотоцикла, 1 автомашина, 2 бронемашины, 1 тягач с прицепом, груженный боеприпасами, а также ранено 110 солдат и офицеров войск вермахта и захвачен 1 пленный. 
Кроме этого, было захвачено 40 винтовок, 4 ручных пулемета, 1 станковый пулемет, 6 автоматов, 2 радиостанции, 2 противотанковых ружья, 3 миномета, 12 повозок с боеприпасами, обмундированием и другим военным имуществом (ЦАМО. Ф. 276. Оп. 811. Д. 7. Л. 74).

В штабе 18 армии (заместитель командующего 18 армией полковник Гайдуков, заместитель начальника оперативного отдела подполковник Лавринович, член Военного совета полковой комиссар Колупаев) исследовали боевую деятельность истребительнодиверсионных отрядов в период с 1 по 15 сентября, после чего были сделаны организационные выводы и отмечены следующие недостатки в боевых действиях отрядов:

- засылались к объектам войск вермахта в непосредственной близости от линии фронта и на непродолжительное время;

- демаскировали себя движением по дорогам и были привязаны к ним;

- в большей степени вели наблюдение за войсками гитлеровской коалиции, мало производили нападений и налетов для уничтожения живой силы и техники войск вермахта;

- были плохо укомплектованы личным составом, в результате чего из отряда 236 стрелковой дивизии во время выполнения боевой задачи дезертировали из караула 6 человек, оказавшиеся впоследствии предателями;

- не представляли вещественные доказательства о боевой деятельности;

- слабо экипированы, отсутствовали специальное горное снаряжение, радиостанции, способные поддерживать постоянную связь отрядов со штабами (ЦАМО. Ф. 276. Оп. 811. Д. 7. Л. 76-77).

Выводы о боевой деятельности истребительно-диверсионных отрядов были следующими:

1. Организация и боевые действия истребительно-диверсионных отрядов в немецком тылу полностью себя оправдали, т.к. значительно дезорганизовали работу тыла, срывали подвоз боеприпасов и продфуража, для охраны транспортов, дорог, мостов и населенных пунктов немцы стали выделять большее количество солдат. Кроме этого, отряды наносили значительные потери в живой силе и материальной части войск гитлеровской коалиции, держали в постоянном напряжении немецкие гарнизоны, чем изматывали их силы.

2. Организация больших отрядов для действия в немецком тылу себя не оправдывала. Малочисленные отряды от 20 до 30 человек имели больше возможностей для маскировки и маневра. действий.

3. Плохая экипировка отрядов в значительной мере снижала эффективность их боевых

4. Отсутствие положительных результатов действий истребительно-диверсионных отрядов 31 стрелковой дивизии свидетельствовало о недооценке этого важного мероприятия командованием дивизии, которое отнеслось формально к укомплектованию отрядов и постановке им задач, следствием чего действия этих отрядов были безрезультатными (ЦАМО. Ф. 276. ОП. 811. Д. 7. Л. 77).

Для усиления эффективности деятельности истребительно-диверсионных отрядов в тылу немецких войск штаб 18 армии представил следующие предложения:

1. Комплектовать истребительно-диверсионные отряды командирами и красноармейцами, тщательно проверенными в боях, не вызывающими никаких сомнений в политической надежности и физически здоровых, а ответственность за комплектование возложить на командиров и комиссаров дивизий.

2. Отряд составлять из 25-30 человек, в числе которых 8-10 автоматчиков, 8-10 стрелков, 3-5 саперов, 1-2 бойцов с противотанковыми ружьями, в зависимости от района действий и характера решаемых задач. В отряде иметь радиостанцию, способную поддерживать связь на удалении до 30 км, вьючный обоз в составе 5-6 вьюков, а также противопехотные и противотанковые мины, взрывчатые вещества, бутылки с горючей смесью.

3. Отряды должны действовать в немецком тылу в течение 5-7 дней и на глубине до 20-30 км от переднего края линии фронта.

4. Метод действий отрядов: движение в тыл противника к объекту и обратно без дорог, используя для этой цели проводников. Удары отрядов по намеченному объекту обязательно производить после тщательной разведки. Захват в плен и уничтожение отдельных лиц 
производить на усмотрение командира отряда и действовать преимущественно бесшумно. В затяжной бой с превосходящими силами противника не вступать, а если есть необходимость и выгодно, то наносить внезапный лихой налет на противника и, захватив с собой необходимое, быстро уходить в лес и горы без дорог.

5. При возвращении в часть отряды должны обязательно предоставлять вещественные доказательства проведенной боевой деятельности (документы, живой пленный, оружие и прочее). При наличии особо важных сведений о действиях или группировке войск вермахта доносить о них немедленно, не дожидаясь своего возвращения, для чего отправлять 2-3 человек во главе со старшим.

6. В каждой дивизии иметь 4 полковых отряда и один дивизионный. Задачи полковым отрядам ставить лично начальникам штабов дивизий, учитывая также интересы полка. Задачи дивизионным отрядам ставить лично начальнику штаба армии, учитывая также интересы дивизии.

7. Личный состав отрядов держать на специальном учете в штабах дивизий и после каждого возвращения представлять к наградам особо отличившихся бойцов и командиров.

8. Отряды в первую очередь обмундировать и экипировать лучшим снаряжением, иметь для них постоянный запас концентратов (ЦАМО. Ф. 276. ОП. 811. Д. 7. Л. 77-78).

В период с 1 по 15 сентября в немецком тылу действовали 5 истребительнодиверсионных отрядов, созданных при штабе 12 армии, 6 отрядов 395 стрелковой дивизии, по 3 отряда в 68 и 16 стрелковых бригадах (ЦАМО. Ф. 467. Оп. 6005. Д. 8о. Л. 68).

Отряд под командованием капитана А.Н. Смирнова действовал в районе дорог Кутаисская - Абхазская в период с 30 августа по 9 сентября. Он установил, что дороги Кутаисская - Саян Поляна, Кутаисская - Хатыпс войсками вермахта не охранялись. На участке выс. 234.9, выс. 290.2 боевые немецкие порядки отсутствовали. Отрядом выявлено наличие боевого охранения войск гитлеровской коалиции непосредственно восточнее Кутаисской, опорного пункта артиллерийской батареи в районе выс. 159.6 и юговосточнее Кутаисской. В Кутаисской располагался штаб 20 моторизованного полка 1 моторизованной дивизии словаков, до батальона пехоты, эскадроны кавалеристов и велосипедистов. В Абхазской выявлен штаб неустановленной части вермахта. В указанный период отряд Смирнова уничтожил 42 солдата, 7 машин, 1 вездеход, повредил 8 направлений связи, захватил 25 винтовок, 2 пистолета, 5 км кабеля, 2 лошади с повозками, 2 противогаза, 12 дисков к пулеметам. В районе 3 км западнее Кутаисской захвачена почта с письмами солдат горно-пушечной батареи 20 моторизованного полка словаков. Взорван мост на дороге из Абхазской на Кутаисскую (ЦАМО. Ф. 467. Оп. 6005. Д. 80. Л. 67-68).

3 сентября из немецкого тыла возвратились в расположение 12 армии истребительнодиверсионные отряды старшего сержанта Гапонова и старшины Олейника. Отрядами было совершено нападение на колонну войск гитлеровской коалиции в районе 1.5 км восточнее выс. 234.9. В результате боевых действий были захвачены 1 ручной пулемет, 7 винтовок, 2 диска к пулемету, документы трех солдат 21 моторизованного полка «Давид» 1 моторизованной дивизии словаков, уничтожено до 25 солдат, а также перерезано 3 телефонные линии. Отряды вернулись без потерь (ЦАМО. Ф. 1721. Оп. 1. Д. 7. Л. 177).

В начале сентября в тылу 12 армии скрывались заключенные, выпущенные из тюрем Краснодара и Усть-Лабинска. Кроме этого, в лесах, особенно у горных речек, скрывались лица, уклонившиеся от призыва в РККА, и дезертиры. В связи с этим 4 сентября 1942 г. был издан приказ № о606/ОП войскам 12 армии, в котором предусматривалось очистить территорию тыла армии от уголовно-преступного элемента, дезертиров и лиц, уклонившихся от призыва в РККА. Для этого следовало привлечь истребительный отряд, кавалерийский дивизион и 12 отдельный батальон противотанковых ружей. Всех задержанных для фильтрации необходимо было направлять в оперативный отдел армии, расположенный в Островской Щели (ЦАМО. Ф. 371. Оп. 6367. Д. 55. Л. 126).

6 сентября 1942 г. состоялось совещание командиров, военных комиссаров, заместителей командиров по материальному обеспечению и начальников политических отделов соединений 12 армии. Из доклада командира 395 стрелковой дивизии Рахимова известно, что в 12 армии было создано 6 истребительно-диверсионных отрядов (3 дивизионных и 3 полковых), боевая деятельность которых была незначительной. Кроме 
этого, в резерве командира 395 стрелковой дивизии был создан дополнительный истребительный отряд (ЦАМО. Ф. 371. Оп. 6367. Д. 55. Л. 123).

Командир 81 стрелковой бригады на совещании указал, что в бригаде было организовано 3 отряда в среднем по 17 человек, которые в тот момент находились на задании за линией фронта. В докладе военного комиссара 68 морской стрелковой бригады сообщалось об одном сформированном истребительном отряде, остальные были на стадии формирования (ЦАМО. Ф. 371. Оп. 6367. Д. 55. Л. 1230б.-124).

В 24 час. оо мин. 7 сентября в подчинение 12 армии вошел 4 гвардейский казачий кавалерийский корпус в составе 32 гвардейской стрелковой дивизии и 9, 11 и 12 гвардейских казачьих кавалерийских дивизий. В командование 12 армией вступил командир 4 гвардейского кавалерийского корпуса гвардии генерал-лейтенант Кириченко, а командующий 12 армией генерал-майор Гречко был назначен командующим 47 армией (ЦАМО. Ф. 47. Оп. 1063. Д. 179. Л. 13-14).

Истребительно-диверсионный отряд 723 стрелкового полка 395 стрелковой дивизии 12 армии действовал за линией фронта в районе дороги Саратовская - Ключевая. Отряд 7 сентября уничтожил 4 автомашины, 36 солдат и офицеров войск гитлеровской коалиции. Из показаний пленного немца известно, что боевые действия истребительно-диверсионных отрядов наносят большие потери войскам вермахта, что влечет страх и панику среди германских войск и их союзников. Советских диверсантов немцы принимают за партизан (ЦАМО. Ф. 1721. ОП. 1. Д. 7. Л. 179об.).

Истребительно-диверсионный отряд 12 армии под командованием старшего лейтенанта И.А. Булавкина в период с 6 по 14 сентября действовал в районе хутора Крутого и 4 км северо-западнее станицы Кутаисской. Отрядом в районе выс. 166.4 (5 км юго-западнее Кутаисской) уничтожено до роты немецкой пехоты, 25 повозок и захвачены документы солдат 20 моторизованного полка словаков. 10 сентября в районе 3 км западнее Кутаисской были уничтожены 2 автомашины с пехотой и захвачены трофеи: 1 ручной пулемет, 1 пистолет и ящик с патронами.

Истребительно-диверсионный отряд 12 армии под командованием младшего лейтенанта С.П. Шунькина в период с 9 по 14 сентября действовал по восточному берегу безымянной реки в районе Поповой Щели, Серного источника, р. Соленой и дороги Саратовская - Черноморская. Отряд уничтожил 1 легковую автомашину с 3 немецкими офицерами и шофером, 1 грузовую автомашину с 9 солдатами и захватил документы (ЦАМО. Ф. 467. Оп. 6005. Д. 80. Л. 68).

Истребительно-диверсионный отряд 12 армии под командованием лейтенанта Борисова с 10 по 16 сентября действовал в районе хутора Веселого и станицы Кабардинской (ЦАМО. Ф. 467. Оп. 6005. Д. 80. Л. 69). Отрядом в районе 3 км севернее Линейной уничтожено 15 германских солдат (ЦАМО. Ф. 276. Оп. 811. Д. 54. Л. 160).

Истребительно-диверсионный отряд 12 армии (во главе лейтенант Забава) в период с 11 по 13 сентября действовал в районе выс. 268.8, где была выявлена огневая система войск вермахта. В ходе рейда отряд потерял трех красноармейцев (1 убит, 2 пропало без вести).

В первой половине сентября истребительно-диверсионные отряды 395 стрелковой дивизии, 16 и 68 стрелковых бригад глубоких рейдов в немецкий тыл не производили, т.к. там действовали только разведывательные группы (ЦАМО. Ф. 467. Оп. 6005. Д. 80. Л. 69).

Приказом войскам Черноморской группы № о05 от 18 сентября части 12 и 18 армий были объединены в 18 армию (командующий генерал-лейтенант Ф.В. Камков) во главе с Военным советом (начальник штаба полковник П.М. Чирков, с 24 сентября - бригадный комиссар Я.В. Гольдштейн) бывшей 18 армии и штабом бывшей 12 армии. Приказом предусматривалось провести объединение двух армий с 18 по 23 сентября (ЦАМО. Ф. 276. Оп. 811. Д. 90. Л. 9).

Армейские (5 отрядов), дивизионные, бригадные и полковые истребительнодиверсионные отряды 18 армии в период с 15 по 30 сентября продолжили свою боевую деятельность в немецком тылу. Армейский истребительно-диверсионный отряд № 1 под командованием капитана Смирнова действовал в районе балки Лисицына, Суздальский, выс. 469.4 и г. Лысая. Отрядом уничтожено свыше 100 солдат, 7 автомашин, 1 вездеход, 20 лошадей, нарушено 8 линий связи, взорван 1 мост, разрушено 3 дзота, захвачено 5 км кабеля, 25 винтовок, 2 пистолета и 2 пленных. 
Истребительно-диверсионный отряд № 2, действовавший в районе Лисицыной Щели и хутора Крутого под командованием старшего лейтенанта Булавкина, уничтожил до 100 солдат, одну санитарную автомашину, 14 повозок, 2 грузовые автомашины, 21 лошадь и 1 ручной пулемет. Отряд захватил 1 пленного, 1 ручной пулемет, 1 пистолет, 9 дисков к ручному пулемету, повредил 12 линий связи и захватил документы.

Истребительно-диверсионный отряд № 3 под командованием младшего лейтенанта Шунькина действовал в районе хутора Головченко, в долине p. Соленой и дороги Саратовская - Кутаисская. Отряд уничтожил 1 грузовую и 1 легковую автомашины, 3 офицеров и 1 солдата. Захвачены 1 револьвер, документы и разное имущество (ЦАМО. Ф. 371. Оп. 6367. Д. 20. Л. 151-1510б.).

Истребительно-диверсионный отряд № 4, действовавший в районе выс. 288.2, выс. 320.0, уничтожил 1 офицера, 67 солдат и совместно с истребительно-диверсионным отрядом № 1 уничтожил 50 солдат, 20 лошадей. Кроме этого, уничтожено 3 дзота с пулеметами и прислугой.

Истребительно-диверсионный отряд № 5 , действовавший в районе Линейной и Абхазской, уничтожил 72 солдата, 4 офицера, 8 велосипедистов, 6 повозок с боеприпасами и 1 грузовую машину. Были повреждены 4 линии связи.

В период с 15 по 30 сентября армейскими истребительно-диверсионными отрядами 18 армии уничтожено 348 солдат, 8 офицеров, 11 грузовых и 1 легковая автомашины, 1 вездеход, 1 санитарная машина, 41 лошадь, 20 повозок, 1 ручной пулемет и повреждено 20 линий связи. Захвачены 1 ручной пулемет, 25 винтовок, 4 пистолета, 5 км кабеля. Взято в плен 3 солдата и разрушено 6 дзотов с пулеметами и прислугой.

Дивизионные истребительно-диверсионные отряды 32 гвардейской стрелковой дивизии, действовавшие в районах Папоротного, Суздальского, Травалева, уничтожили склад боеприпасов, 7 лошадей, нарушили линию связи на протяжении 1 км и захватили 8 ящиков мин.

Полковые истребительно-диверсионные отряды 32 гвардейской стрелковой дивизии, действовавшие в районах выс. 290.2, выс. 288.0, хутор Веселый, выс. 317.2, уничтожили 1 склад боеприпасов, 1 склад продовольствия, 5 грузовых машин, 2 мотоцикла, кухню, 75 солдат, ранили 20 солдат, повредили 5 линий связи, захватили в плен 1 солдата и документы (ЦАМО. Ф. 371. Оп. 6367. Д. 20. Л. 1510б.).

Для проведения диверсии в немецком тылу из красноармейцев 1 стрелкового батальона 818 стрелкового полка 31 стрелковой дивизии (15 человек) и из партизан отряда под командованием первого секретаря Апшеронского районного комитета ВКП(б)з. C.С. Жукова был составлен отряд в количестве 27 человек. Командовал сводным истребительно-диверсионным отрядом старший лейтенант Сухопаров. Отряд на рассвете 27 сентября совершил диверсионный налет на немецкий гарнизон, расположенный в населенном пункте Конобоз (1.5 км северо-восточнее отм. 960.1). Налет на казарму был неожиданным для немцев, т.к. они не успели одеться и были застигнуты в нижнем белье. Ручными гранатами и огнем автоматов было убито и ранено более 70 человек. Противотанковая пушка и два станковых пулемета были подорваны на месте. Отрядом захвачены 1 миномет, 1 телефонный аппарат, 1 станковый и 2 ручных пулемета. Потери сводного отряда составили 5 человек убитыми и ранеными, в том числе 2 партизана (ЦАМО. Ф. 7476. Оп. 153874с. Д. 1. Л. 7).

Из воспоминаний командира Апшеронского партизанского отряда Жукова известно, что в Конобозе погибли второй секретарь районного комитета ВКП(б) П.П. Малько, супруги Валентин Захарович и Августа Евтропьевна Стакановы и три красноармейца. Тяжелое ранение получили партизаны Ф.Г. Кравченко, Н.С. Ильин, А.М. Мартыненко (Тюменцев, 2016: 256).

Другой истребительно-диверсионный отряд 31 стрелковой дивизии действовал в немецком тылу в районах Самурской, выс. 466.2 (4 км северо-западнее Самурской), выс. 464.2, Острого Шпиля, Полустана и дороги Сухая Кочевка - Полустан. Отряд разгромил 29 сентября обоз противника, двигавшийся из Самурской в сторону станицы КубаноАрмянской. В перестрелке убито 2 офицера и 15 солдат войск вермахта, уничтожено

3 ВКП(б) - Всесоюзная коммунистическая партия (большевиков). 
12 парных повозок с лошадьми, захвачен в плен бывший красноармеец (ЦАМО. Ф. 371. Оп. 6367. Д. 102. Л. 1410б.).

Дивизионные истребительно-диверсионные отряды 395 стрелковой дивизии действовали в районах станиц Кутаисской, Саратовской, Свердловской, Кубанской, выс. 172.8. Уничтожили 95 солдат, 1 грузовую машину, 11 подвод, 2 лошади. Захватили 5 кавалерийских лошадей с седлами, 180 мин, 23 противотанковые гранаты, 5 ручных гранат, 50 мотков телефонного кабеля, 1 буссоль 4 , 1 миномет с угломером.

Полковые истребительно-диверсионные отряды 395 стрелковой дивизии, действовавшие в районах Ключевой, Кубанской, выс. 198.5, уничтожили 168 солдат, 3 офицеров, 1 легковую и 5 грузовых автомашин, 1 ручной пулемет, 8 винтовок и 1 телефонный аппарат.

Истребительно-диверсионные отряды 68 морской стрелковой бригады, действовавшие в районах высот 268.8, 288.0, 320.0, уничтожили 29 солдат, захватили 1 автомат, 1 карабин, 2 винтовки, 1 клинок, 1000 советских рублей и документы.

Истребительно-диверсионный отряд 236 стрелковой дивизии, действовавший в немецком тылу в районе Самурской, захватил 1 пленного.

Истребительно-диверсионные отряды 383 стрелковой дивизии действовали в районах Кубано-Армянском, Озерова, дороги Нефтяная - Белая Глина, Хадыженского, Суздальского, Травалева, Папоротного, Червякова. Было уничтожено 210 солдат, 5 офицеров, 2 бронемашины, 1 гусеничный тягач с прицепом, груженный боеприпасами, 2 грузовые машины, 10 мотоциклов, 16 подвод с боеприпасами и обмундированием. Захвачено 16 винтовок, 3 ручных пулемета, 7 автоматов, 1 радиостанция, 10 гранат, 2 револьвера, патроны, обмундирование и документы (ЦАМО. Ф. 371. Оп. 6367. Д. 20. Л. 152-1520б.).

Истребительно-диверсионный отряд 966 артиллерийского полка 383 стрелковой дивизии в период с 17 по 21 сентября действовал в немецком тылу. В районе Озерова по дороге на Белую Глину отряд совершил налет на колонну войск вермахта в составе 10 подвод и до двух рот солдат, в результате чего миной была подорвана повозка с пулеметной установкой, убито 12 солдат, 1 офицер и 3 лошади. При проведении разведки в Нефтегорске 19 сентября отряд был обнаружен местными жителями, которые о расположении отряда донесли немецкому командованию, после чего отряд был обстрелян артиллерийскоминометным огнем и вынужден был отойти от Нефтегорска к выс. 480.0. Немцами была выслана группа преследования в составе 60 человек, отряд боя не принял и вернулся в расположение части.

Истребительно-диверсионным отрядом 966 артиллерийского полка установлено, что в районе Озерова и Нефтегорска оборонительных инженерных сооружений не имелось и не производилось. По сведениям от жителей Нефтегорска, немецкие танки и частично немецкая пехота 16 сентября были отправлены по дороге в направлении Апшеронской. Была обнаружена гаубичная артиллерийская батарея калибра 150-мм на северо-восточной окраине Нефтегорска. В районе Озерова и Нефтегорска преимущественно находились поляки и гораздо меньше немцев, т.к. очевидно, что была произведена замена немецких частей. Добытые сведения требовали проверки (ЦАМО. Ф. 1704. Оп. 1. Д. 16. Л. 66-66об.).

По поводу информирования местными жителями командования войск вермахта имеются следующие сведения: из воспоминаний Л.А. Филимоновой, служившей в 53 отдельном зенитно-артиллерийском дивизионе РККА, известно, что среди жителей Кубани и Крыма было много предателей, которые активно сотрудничали с войсками гитлеровской коалиции. Например, в Крыму местные жители корректировали огонь немецкой артиллерии. В ноябре 1943 г., когда дивизион находился в Темрюке, оказалось, что большинство местных жителей ушло с отступающими войсками вермахта, а оставшиеся были настроены враждебно к советским воинам (Коллаборационизм..., 2003: 62-63).

Всего истребительно-диверсионными отрядами 18 армии с 15 по 30 сентября уничтожено: 18 офицеров, 1113 солдат, 8 велосипедистов, 76 лошадей, 1 орудие, 2 бронемашины, 3 пулемета, 8 винтовок, 24 грузовые и 2 легковые автомашины,

\footnotetext{
4 Буссоль - один из приборов управления огнем артиллерии. Служит для целеуказания, изучения местности и целей, наблюдения во время стрельбы, топографической привязки огневых позиций и наблюдательных пунктов.
} 
12 мотоциклов, 1 вездеход, 1 санитарная машина, 59 повозок, 2 склада с боеприпасами, 1 склад с продовольствием, 1 кухня, 1 тягач, 6 дзотов с пулеметами и прислугой. Повреждено до 30 линий телефонной связи. В указанный период захвачено: 6 пленных, 5 пулеметов, 44 винтовки, 8 автоматов, 6 пистолетов, 250 мин, 40 ручных гранат, 1 миномет, 1 рация, 1 буссоль, 5 лошадей, а также документы, обмундирование и большое количество патронов (ЦАМО. Ф. 371. Оп. 6367. Д. 20. Л. 1520б.).

В течение сентября истребительно-диверсионные отряды 56 армии не были задействованы, т.к. в тылу войск вермахта в большей степени действовали разведывательные отряды (ЦАМО. Ф. 412. Оп. 10282. Д. 52. Л. 115-1320б.).

В то же время командование 56 армии наградило командира первого армейского истребительно-диверсионного отряда лейтенанта У.Д. Мастерко, командира второго армейского истребительно-диверсионного отряда лейтенанта М.В. Кугуелова медалью «За отвагу». Отряды Мастреко и Кугуелова совместно ликвидировали 4 сентября командира 198 пехотной дивизии войск вермахта генерал-майора фон Бука в районе дороги Маслов Пензенская - Бакинская (ЦАМО. Ф. 33. Оп. 682525. Д. 268. Л. 144-145).

Следует согласиться с мнением исследователя И.В. Киселева, что убийство Бука стало следствием боевых действий разведывательной группы 723 стрелкового полка 395 стрелковой дивизии 12 армии. В день и на месте ликвидации фон Бука был захвачен в плен советский разведчик, который на допросе сообщил немецкому командованию о своей принадлежности к 723 стрелковому полку. Ликвидация генерал-майора фон Бука и начальника оперативного отдела дивизии майора И. Буля произошла 6 сентября на дороге Горячий Ключ - Саратовская (Киселев, 2020: 127).

Из записи, сделанной 7 сентября, в журнале боевых действий 723 стрелкового полка, известно, что накануне в направлении перекрестка дорог 3 км северо-восточнее Ключевой действовала усиленная разведывательная группа в количестве 72 человек. На профилированной дороге ее налетом уничтожено 2 автомашины и нанесены потери немцам в живой силе. В ходе перестрелки с германскими автоматчиками группа понесла потери: 4 человека ранено и 6 человек пропало без вести (ЦАМО. Ф. 7377. Оп. 220517. Д. 10. Л. 240б.).

Немецкий исследователь В. Тике также указывает, что именно 6 сентября командир 198 пехотной дивизии генерал-майор фон Бук, начальник оперативного отдела штаба майор Буль и их водитель фельдфебель Глокенбах попали в советскую засаду на шоссе Ключевская - Саратовская и погибли (Тике, 2005: 98-100). Из этого следует, что ликвидацию немецких офицеров произвели разведчики из 723 стрелкового полка.

В первой половине сентября 1942 г. части и соединения 47 армии вели оборонительные бои на северо-восточных окраинах Новороссийска и не дали немецким войскам развить наступление в направлении Кабардинки и Геленджика. С 20 по 24 сентября на левом фланге Черноморской группы войск правофланговые части 47 армии вели оборонительные бои с частями 3 пехотной дивизии румын, наступавшими из района югозападнее Ахтырской на поселок Эриванский. Войска гитлеровской коалиции стремились выходом в тыл 47 армии в район Геленджика - Кабардинки ликвидировать ее и полностью овладеть Цемесской бухтой (ЦАМО. Ф. 47. Оп. 1063. Д. 179. Л. 1). В сентябре также не было отмечено боевых действий истребительно-диверсионных отрядов 47 армии.

Из воспоминаний бельгийского добровольца легиона «Валлония» Леона Дегрелля известно, что в сентябре 1942 г. войска вермахта приступили к перегруппировке, и именно в этот период в немецком тылу началась жестокая, дерзкая, часто невидимая и всегда смертоносная партизанская война. В сентябре подразделения легиона были расквартированы в Кубано-Армянской станице. Местное армянское население было настроено враждебно к советской власти и охотно сотрудничало с войсками гитлеровской коалиции, предоставляя разведывательную информацию и проводников (Дегрелль, 2013: 97).

Дегрелль ошибочно полагал, что в тылу войск вермахта действуют отряды партизан. На самом деле там вели боевые действия истребительно-диверсионные отряды Черноморской группы войск, которые наносили потери в живой силе и технике войскам противника. Активная оборона действиями истребительно-диверсионных отрядов в тылу войск Третьего рейха давала положительные результаты. Дегрелль указывал, что связь с вышестоящим командованием была только по радио, сообщение с тылом требовало 
регулярных экспедиций, на которые выделяли половину батальона бельгийского легиона. Бельгийские легионеры находились в постоянном напряжении и даже на отдыхе не снимали обмундирования и держали оружие в боевой готовности (Дегрелль, 2013: 98-99).

Активные боевые действия истребительно-диверсионных отрядов Черноморской группы войск вынудили немецкое командование усилить свой тыл из числа коллаборационистов. Сотрудничающий с германским командованием, бывший царский генерал Краснов приступил к формированию 7-й добровольческой казачьей дивизии. Штаб был расположен в рабочем городке железнодорожной станции Краснодар-2 (Коллаборационизм..., 2003: 21).

В середине октября 7 добровольческая казачья дивизия, сформированная из кубанских и донских казаков, входила в состав армейского резерва войск вермахта, она дислоцировалась в районе Тохтамукай и Понежукай (ЦАМО. Ф. 47. Оп. 1063. Д. 180. Л. 30б.-4).

Перед фронтом 18 армии и Лазаревской группы войск (группа создана 5 октября 1942 г.), в немецком тылу, в октябре из жителей Тульского и Майкопского районов путем вербовки добровольцев и мобилизации молодежи 1923-1924 годов рождения были созданы 4 казачьи сотни. Добровольцам, вступившим в них, германским командованием выдавалось вознаграждение в сумме 600 рублей и 16 кг муки (Коллаборационизм..., 2003: 26).

В этот период был создан армейский резерв войск гитлеровской коалиции: добровольческий казачий отряд в районе Нефтяной, 373 батальон бельгийского легиона в районе Суздальском, 781 батальон Туркестанского легиона в районе хутора Куринского (ЦАМО. Ф. 47. ОП. 1063. Д. 180. Л. 40б.).

Во второй половине октября в станице Ширванской дислоцировался батальон крымских татар, а в станице Баговской - азербайджанский легион в количестве 1500 человек (Коллаборационизм..., 2003: 22, 24).

В целях усиления немецкого тыла перед фронтами 56 и 47 армий для борьбы с истребительно-диверсионными отрядами командование войск гитлеровской коалиции создает из местного населения казачьи сотни в станицах Ильской, Северской и Афипской. В Верхне-Баканской - был сформирован казачий отряд из 150 местных жителей, которым командовал немецкий офицер. Команды из местных жителей охраняли стратегические объекты, такие как железнодорожные пути, для чего обходчики использовали собак (Коллаборационизм..., 2003: 18-19, 26).

Украинская добровольческая дивизия, сформированная из украинцев, была расквартирована в районе Абинской, Ново-Дмитриевской, Смоленской и Северской. Кроме этого, украинский истребительный отряд дислоцировался в районе Ильской (ЦАМО. Ф. 47. Оп. 1063. Д. 180. Л. 3-4).

В сентябре 1942 г. Черноморская группа войск наращивала свою оборону на участках 18 и 56 армий, где должен был состояться главный удар немецких войск в направлении Туапсе. 23 сентября началось большое осеннее наступление войск гитлеровской коалиции на Туапсе, готовившееся под кодовым наименованием «Аттика». Наступление было произведено с трех оперативных направлений. На правом фланге (западном) действовал 57 танковый корпус с частями 125, 198 немецких пехотных дивизий и 1 моторизованной дивизией словаков. Эти силы обеспечивали правый фланг наступательной группировки, а затем должны были поддержать наступление 44 егерского корпуса. В центре вел боевые действия 44 егерский корпус, 101 егерская дивизия которого вела наступление на правом фланге, а 97 егерская дивизия - на левом. Корпус должен был наступать по обе стороны дороги на Туапсе. На восточном левом фланге перешел в наступление 49 горнострелковый корпус с горнострелковой дивизией «Ланц» и 46 пехотной дивизией. В задачу 46 пехотной дивизии входило обеспечение левого фланга и продвижение за наступающей группировкой. Горнострелковая дивизия «Ланц» должна была из района Нефтяной наступать через гору Гунай, населенные пункты Гойтх, Индюк в южном направлении и открыть путь к прибрежной дороге фланговым ударом (Тике, 2005: 212-218).

В ходе начавшегося наступления на Туапсе были выявлены удары немецких войск в направлении Лазаревской по долине р. Пшеха. Для удобства управления за счет правого крыла 18 армии части Лазаревского направления 5 октября были выделены в отдельную оперативную группу: 31 стрелковая дивизия - 75, 177, 248, 818 стрелковые полки, 691 стрелковый полк 383 стрелковой дивизии, 11 гвардейская кавалерийская дивизия и одна 
батарея 152-мм пушек 547 армейского артиллерийского полка. Лазаревскую группу войск возглавил полковник В.А. Гайдуков (Taran, 2021a: 53).

11 октября Ставка Верховного Главнокомандования освободила от должности командующего Черноморской группой войск генерал-полковника Я.Т. Черевиченко и назначила командующим группой генерал-майора И.Е. Петрова (Гречко, 1967: 160).

В период наступления немецких войск на Туапсе боевая активность истребительнодиверсионных отрядов носила незначительный характер, отряды Лазаревской группы войск и 47 армии боевых действий не вели. Только в двадцатых числах октября возобновили боевые действия в немецком тылу отряды 56 и 18 армий (ЦАМО. Ф. 276. Оп. 811. Д. 28. Л. 248-272; там же Д. 18. Л. 8-31).

Истребительно-диверсионный отряд 56 армии, действовавший в тылу войск вермахта, боем занял отдельные дома 2 км юго-восточнее Маслова и захватил трофеи - 4 станковых пулемета. В районе станицы Пензенской 21 октября отряд захватил в плен М.Х. Мамаева, кабардинца по национальности, который на допросе сообщил, что 25 мая 1942 г. он был взят в плен немецкими войсками на Харьковском направлении. Из советских пленных, представителей кавказских национальностей и русских, было отобрано 500 человек, которые на территории Польши прошли обучение боевой подготовке. Из бывших красноармейцев сформировали батальон четырехротного состава, переодели в немецкую форму и перебросили на Северный Кавказ в район станицы Пензенской (ЦАМО. Ф. 412. Оп. 10282. Д. 52. Л. 155-1550б.).

Из журнала боевых действий 56 армии известно, что армейским истребительнодиверсионным отрядом под командой лейтенанта Кугуелова была сделана смелая вылазка в тыл войск вермахта. Он выдвинулся к шоссе Калужская - Ново-Дмитриевская, где в течение трех суток бойцы отряда вели наблюдение, собрав ценные сведения о немецких войсках. Установив движение машин по дороге, решили устроить засаду с целью захвата пленного, для этого лейтенант Кугуелов отобрал восемь человек - старшего сержанта Мартынова, сержанта Чжуна, старшего сержанта Калинина, красноармейца Давидошвили, старшину Зубенко, старшего сержанта Лахина, старшего сержанта Вдовина и заместителя политрука Темелькова (ЦАМО. Ф. 412. Оп. 10282. Д. 52. Л. 156об.).

24 октября к месту организованной засады приблизилась крытая автомашина, и бойцы отряда бросили под ее колеса гранаты. Лейтенант Кугуелов первым выскочил из засады, расстреливая из автомата сидевших в кузове немцев, но был убит. Бойцы отряда, последовавшие за командиром, уничтожили 22 офицера из летного состава. Встревоженные взрывами и выстрелами немцы выслали из станицы Калужской автомашину с автоматчиками и конный отряд. Бойцы отряда, захватив портфель с документами, трофейное оружие и тело лейтенанта Кугуелова, ушли в лес. Из захваченных документов установлено, что были уничтожены 22 немецких летчика, направлявшихся на один из своих аэродромов (ЦАМО. Ф. 412. Оп. 10282. Д. 52. Л. 156об.-157.).

В это время истребительно-диверсионный отряд 30 стрелковой дивизии 56 армии под командованием младшего лейтенанта Будникова внезапным налетом на штаб 24 строительного батальона войск вермахта уничтожил 23 солдата и офицера, конюшню с 35 лошадьми, 2 т фуража и продовольствия, до 19 винтовок. Захвачены трофеи: 6 винтовок, 1 телефонный аппарат, вещевое имущество и документы (ЦАМО. Ф. 412. Оп. 10282. Д. 52. Л. 1590б.).

На участке обороны 18 армии войска вермахта, прорываясь в юго-западном направлении, 5 октября овладели Гунайкой. 21 октября, после завершения перегруппировки дивизии «Ланц», немцы прорвались в долину р. Пшиш. Населенные пункты Перевальный и Гойтх оказались в руках боевых групп Бухнера на правом фланге и Лаваля - на левом фланге. Прорвав фронт 40 мотострелковой бригады и 408 стрелковой дивизии 18 армии, немецкие войска продолжили наступление в южном и юго-западном направлении и заняли горы Семашхо и Каменистую (22 км по прямой до Туапсе), отдельными группами вышли на безымянную высоту восточнее г. Индюк. Предпринятым контрнаступлением частей и соединений правого крыла 18 армии дальнейшее продвижение войск гитлеровской коалиции было остановлено (ЦАМО. Ф. 47. Оп. 1063. Д. 180. Л. 8; Тике, 2005: 228-230).

Прорыв немецких войск в направлении Туапсе осложнил оперативную обстановку на участке обороны 18 армии. В конце октября была возобновлена деятельность 
истребительно-диверсионных отрядов 18 армии, один из которых с 28 по 30 октября действовал в тылу войск вермахта. Отрядом была уничтожена группа немцев и захвачен в плен 1 солдат. Последующими действиями отряд уничтожил еще одну немецкую группу и 15 вьючных лошадей. Всего было уничтожено свыше 50 немецких солдат. В балке Островская Щель были захвачены повозки с мукой, которые передали 9 стрелковой бригаде. Потери отряда: убито и ранено 4 человека (ЦАМО. Ф. 371. Оп. 6367. Д. 102. Л. 158-159).

В ноябре командование войск вермахта для борьбы с истребительно-диверсионными отрядами, действующими в немецком тылу, продолжило создание добровольных казачьих формирований из местного населения, а также использовало представителей иных национальностей из советских республик. В станице Абадзехской располагался штаб полка имени Платова, составленный из военнопленных красноармейцев РККА, а в станице НовоСвободной дислоцировалось две сотни казаков-добровольцев. Кроме этого, в Майкопе был расквартирован армянский батальон в количестве 6оо человек (Коллаборационизм..., 2003: 24-26).

В течение ноября истребительно-диверсионные отряды 16 отдельного стрелкового корпуса (Лазаревская группа войск) действовали в тылу противника в районе хутора Армянские, Черниговского, Кубано-Армянского, Измайловского, Червякова, Котловины, Маратуки, г. Оплепен, высот 426.7, 435.3 и 740.9. Отряды корпуса организовывали засады, нападали на обозы, отдельные группы войск вермахта и уничтожали проводную связь, захвачено было двое пленных, взорван склад боеприпасов. При уничтожении обозов было истреблено большое количество немецких солдат и офицеров. Захвачен один станковый пулемет. Добыто много ценных разведывательных данных. Ввиду активных боевых действий истребительно-диверсионных отрядов 16 отдельного стрелкового корпуса в немецком тылу войска гитлеровской коалиции для охраны своих обозов, состоящих из 5-6 повозок или вьюков, как правило, для сопровождения выделяли отряды в составе от 30 до 40 человек. Движение одиночных солдат и групп в количестве от 3 до 5 человек немцы не практиковали (ЦАМО. Ф. 276. Оп. 811. Д. 12. Л. 10ооб.).

В первой половине ноября в тылу войск вермахта действовали истребительнодиверсионные отряды 383 стрелковой дивизии 18 армии, каждый в количестве 31 человека. Было произведено 3 рейда в немецкий тыл. С 1 по 5 ноября истребительно-диверсионный отряд 696 стрелкового полка под командой ефрейтора Демидова действовал в районе выс. 994.2 и Котловина, где отрядом произведена разведка и в двух направлениях была повреждена телефонная связь. В прифронтовой зоне отряд ефрейтора Демидова овладел выс. 994.2 и удерживал ее в течение двух дней. В ходе боевых действий отрядом уничтожено более 40 немецких солдат и офицеров.

Истребительно-диверсионный отряд 694 стрелкового полка под командой младшего лейтенанта В.И. Андреева с 5 по 10 ноября в результате боевых действий произвел разведку в районе Гунайки, Гойтха, уничтожил 20 немецких солдат и 3 дзота на выс. 977.о, была парализована в двух направлениях телефонная связь.

С 5 по 10 ноября истребительно-диверсионный отряд 465 отдельной моторизованной разведывательной роты действовал в районе Гунайки. В указанный период отрядом уничтожено 32 солдата и офицера войск гитлеровской коалиции, 1 станковый пулемет, 20 винтовок, 7 горных мулов с вьюками. Захвачено 3 автомата, 700 патрон, 5 винтовок и 20 гранат (ЦАМО. Ф. 1704. ОП. 1. Д. 30. Л. 49).

С 1 по 22 ноября в тылу войск вермахта в районе выс. 230.4, населенных пунктов Гунайка, Перевальный и г. Гунай действовал истребительно-диверсионный отряд 18 армии в количестве 40 человек под командованием капитана Смирнова. Отрядом уничтожено 80 солдат и офицеров, 2 автомашины с грузом, 15 вьючных лошадей, 2 радиостанции и 2 телефонных аппарата, а также повреждены телефонные линии связи. Захвачены 1 ручной пулемет, 15 винтовок, 6 подвод с мукой, 6 пленных и много ценных документов (ЦАМО. Ф. 47. Оп. 1063. Д. 125. Л. 63).

В этот же день, 22 ноября, отряд капитана Смирнова в количестве 27 человек убыл за линию фронта в район Гунайки, где в течение недели он нарушил нормальное движение транспортов и деморализовал немецкие тылы. На г. Гунай смелыми действиями отряда уничтожено 15 солдат и офицеров войск вермахта, 2 радиостанции армейского типа, 
принадлежавшие авиаполку связи, захвачено 5 пленных радистов и много ценных документов. Потери отряда - 2 убитых (ЦАМО. Ф. 47. Оп. 1063. Д. 181. Л. 13).

С 22 по 29 ноября истребительно-диверсионный отряд 18 армии в количестве 35 человек под командованием лейтенанта В.И. Ширшакова действовал в немецком тылу в районе Котловины, Перевального, Гунайки. Отряд уничтожил 120 солдат и офицеров, захватил ценные документы. Потери отряда: ранено 3 человека.

Истребительно-диверсионный отряд 18 армии под командованием лейтенанта Шумкина в количестве 20 человек с 23 по 30 ноября действовал в районе Червякова, Красного Кладбища, Гунайки, Котловины, где было уничтожено 15 солдат и офицеров, захвачен 1 ручной пулемет и ценные разведданные. Отряд возвратился без потерь.

С 25 по 28 ноября истребительно-диверсионный отряд 18 армии в количестве 20 человек под командованием старшего лейтенанта Штуля вел боевые действия в районе дороги Гойтх, г. Семашхо, г. Каменистой, Гунайки. Отряд уничтожил 50 солдат и офицеров, 11 вьючных лошадей, захватив 11 винтовок, 16 автоматов и папку с документами. Потери отряда: убито 2 человека (ЦАМО. Ф. 47. Оп. 1063. Д. 125. Л. 64).

Армейский истребительно-диверсионный отряд 18 армии, действовавший в районе дорог Красное Кладбище - Червяков, в период с 24 ноября по 1 декабря уничтожил 15 немецких солдат и захватил 1 зенитный пулемет (ЦАМО. Ф. 276. Оп. 811. Д. 56. Л. 340).

Из писем, взятых в ноябре 1942 г. у убитых немецких солдат на участке обороны 353 стрелковой дивизии 18 армии, известно, что немцы воспринимали диверсионные действия русских в своем тылу боевой деятельностью партизан. Также в письмах отмечалось, что из-за диверсий подвоз продовольствия и боеприпасов был затруднен (ЦАМО. Ф. 1673. ОП. 1. Д. 23. Л. 62).

С 1 по 15 ноября истребительно-диверсионный отряд 30 стрелковой дивизии 56 армии в количестве 15 человек под командованием сержанта Ломановского вел боевую деятельность в районе Калужских Нефтепромыслов, Супском, Ставропольском. Было уничтожено 35 солдат, 1 офицер и захвачен в плен бывший житель Дефановки Яковенко, служивший у немцев шофером в 8 автоколонне 125 пехотной дивизии. Потери отряда: убит 1 и ранен 1 красноармеец.

Истребительно-диверсионный отряд 68 морской стрелковой бригады 56 армии в количестве 22 человек под командованием сержанта Плохих с 3 по 6 ноября действовал в районе Трех Дубов и выс. 620.8. В ходе боевых действий отрядом рассеяно до роты пехоты, уничтожено 20 солдат, минирована дорога в районе Трех Дубов. Потери отряда: убито 4 человека.

С 7 по 9 ноября отряд 56 армии в количестве 25 человек под командой лейтенанта Голузова вел боевые действия в немецком тылу. Отрядом уничтожены 1 офицер, 1 крытая автомашины с солдатами, количество которых не установлено, в четырех местах перерезан телефонный кабель (ЦАМО. Ф. 47. Оп. 1063. Д. 125. Л. 64).

Во второй половине ноября 7 дивизионных и бригадных истребительнодиверсионных отрядов 56 армии пытались безуспешно вести боевую деятельность в тылу войск вермахта. Отряды сержанта Плохих и лейтенанта Кононкова дважды предпринимали попытки действовать в немецком тылу, но безрезультатно. В отношении деятельности нескольких отрядов командование 56 армии проводило расследования (ЦАМО. Ф. 47. ОП. 1063. Д. 125. Л. 65).

Во второй половине ноября на участке обороны 56 армии отмечалось, что войска вермахта впереди основной обороны выдвинули наблюдательные посты с «кукушками», т.е. немецкие снайпера отслеживали перемещение диверсионных групп РККА, следующих в тыл войск гитлеровской коалиции. Для предотвращения проникновения истребительнодиверсионных и разведывательных отрядов Черноморской группы войск немцы стали усиливать посты служебными собаками (ЦАМО. Ф. 1721. Оп. 1. Д. 13. Л. 108).

Нужно отметить, что противник активно использовал служебных собак. Например, для выявления огневых точек и расположения боевых порядков на участке 137 полка морской пехоты 47 армии 24 сентября войска вермахта применили специально обученных собак, которые при обнаружении бойцов РККА и огневых точек давали знать и лаяли, после чего гитлеровцы вели артиллерийский огонь по обнаруженным местам (ЦАМО. Ф. 276. Оп. 811. Д. 54. Л. 319). 
В ноябре 1942 г. приступили к проведению боевых действий отряды 47 армии. С 1 по 6 ноября в немецком тылу действовал истребительно-диверсионный отряд 47 армии в количестве 19 человек под командованием лейтенанта Коночева. Отряд произвел минирование шоссейной дороги Неберджаевская - Крымская, в результате чего были уничтожены 7 солдат, 2 автомашины, 3 подводы и 1 бензобак.

Истребительно-диверсионный отряд 47 армии в количестве 18 человек под командованием младшего лейтенанта Смирнова с 1 по 15 ноября вел боевые действия в тылу войск гитлеровской коалиции. В указанный период было произведено две попытки выхода за линию фронта, но в первом случае отряд возвратился без результатов вследствие исчезновения одного бойца. В следующем выходе в тыл убито 8 германских солдат.

Следующие 4 попытки выхода истребительно-диверсионных отрядов 47 армии в немецкий тыл оказались безрезультатны: вследствие плохой погоды поставленные задачи не были выполнены (ЦАМО. Ф. 47. Оп. 1063. Д. 125. Л. 66).

В течение ноября 1942 г. в ходе боевых действий истребительно-диверсионных отрядов Черноморской группы войск в немецком тылу было уничтожено: солдат и офицеров войск гитлеровской коалиции - 355, вьючных лошадей -26 , автомашин с грузом и войсками -5 , подвод с грузом - 9, радиостанций - 2, телефонных аппаратов - 2 и 1 бензобак. Захвачено трофеев: винтовок - 26, автоматов - 16, пулеметов - 2, радиостанций -1 , лошадей -5 , пленных -8 , а также большое количество ценных документов. Потери истребительнодиверсионных отрядов: убито - 9, ранено - 4, пропал без вести - 1 (ЦАМО. Ф. 47. Оп. 1063. Д. 125. Л. 670б.).

25 ноября 46 армия генерал-лейтенанта Леселидзе, действовавшая на перевалах центральной части Главного Кавказского хребта, вошла в подчинение Черноморской группы войск. В 46 армии истребительно-диверсионные отряды не создавались, т.к. в немецком тылу успешно действовали разведывательные отряды, которые давали не только ценную информацию о действиях войск вермахта, но и наносили потери живой силе и технике противника (ЦАМО. Ф. 401. Оп. 9511. Д. 9. Л. 76-77).

В декабре 1942 г. немецкое командование продолжает формировать немецкие гарнизоны на Кубани, используя для этого казаков-добровольцев и представителей других национальностей:

- Бесленеевская - до роты азербайджанцев и 100 полицейских.

- Губская - до батальона азербайджанцев.

- Баракаевская - до роты азербайджанцев и 150 полицейских.

- Абадзехская - до 3 эскадронов казаков и до батальона азербайджанцев.

- Ярославская - до эскадрона казаков и до 80 полицейских.

- Ново-Свободная - до эскадрона казаков.

- Баговская - до двух рот азербайджанцев.

- Дагестанская - эскадрон казаков и взвод немцев.

- Даховская - эскадрон казаков, рота азербайджанцев, рота немцев.

- Нижегородская - до взвода немцев, взвод азербайджанцев, 60 полицейских.

- Каменномостская - до 2 эскадронов казаков.

- Костромская - до взвода немцев, обоз русских военнопленных - 150 человек.

- Хамкетинская - до 2 рот азербайджанцев (Коллаборационизм..., 2003: 27).

В станице Крымской немецкий гарнизон состоял из 4 сотен кубанских и донских казаков, а во второй половине декабря в Мостовской, Губской, Богаевской и других станицах рассредоточился полк донских казаков. В станице Черниговской было сосредоточено до кавалерийского полка казаков (1000 сабель), а в станице Рязанской военному делу обучалось 1500 молодых казаков (Коллаборационизм..., 2003: 27-28).

В период с 1 по 5 декабря вследствие шедших проливных дождей, полного бездорожья, отсутствия теплого обмундирования, исправной обуви и необходимого продовольствия истребительно-диверсионные отряды 16 отдельного стрелкового корпуса не действовали. В дальнейшем предпринятые действия отрядов в немецком тылу носили в большей степени разведывательный характер (ЦАМО. Ф. 849. Оп. 1. Д. 4. Л. 81).

Истребительно-диверсионный отряд 16 отдельного стрелкового корпуса в районе хутора Армянские 23 декабря уничтожил 17 немецких солдат и офицеров и захватил 
9 лошадей, 3 пистолета, 1 фотоаппарат и документы штабной батареи 115 артиллерийского полка (Taran, 2021a: 62).

В расположение частей 18 армии 7 декабря возвратились истребительно-диверсионные отряды № 2 и 5, находившиеся в немецком тылу с 30 ноября. Отряд № 2 в составе 30 человек под командованием лейтенанта Ширшакова, действовавший в районе Гунайки, уничтожил 5 солдат и офицеров войск вермахта, повредил 2 телефонные линии. Отряд № 5 в количестве 18 человек под командованием лейтенанта Алексеенко, действуя в районе дорог Котловина - Маратуки и южнее Гунайки, уничтожил 15 немецких солдат и 5 подвод с продовольствием (ЦАМО. Ф. 371. ОП. 6367. Д. 102. Л. 181).

С 2 по 10 декабря в районе восточнее Котловины, высот 975.7, 695.6 и 307.2 в немецком тылу действовал истребительно-диверсионный отряд 40 мотострелковой бригады 18 армии в количестве 27 человек. Он захватил 3 пленных, повредил телефонную линию на участке Маратуки, Котловина, Правая Туха и телеграфную линию в районе Гунайки, Нефтегорска. Потери отряда: убит - 1, ранены - 5 человек (ЦАМО. Ф. 276. Оп. 811. Д. 56. Л. 641).

Истребительно-диверсионный отряд 32 гвардейской стрелковой дивизии 18 армии в период с 2 по 10 декабря действовал в тылу войск гитлеровской коалиции в районе Навагинской, высот 576.0 и 527.0, где повредил телефонную станцию и вырезал несколько км кабеля (ЦАМО. Ф. 371. Оп. 6367. Д. 93. Л. 24об.; там же Ф. 276. Оп. 811. Д. 56. Л. 340, 641).

Истребительно-диверсионный отряд 30 стрелковой дивизии 56 армии в составе 17 человек под командой лейтенанта Кононкова с 6 по 11 декабря действовал в районе 1 км восточнее выс. 188.8, в результате его действий убито 7 солдат вермахта (ЦАМО. Ф. 276. Оп. 811. Д. 134. Л. 10б.). Во второй половине декабря 1942 г. 30 стрелковая дивизия за боевые заслуги была переименована в 55 гвардейскую стрелковую дивизию (ЦАМО. Ф. 1172. Оп. 1. Д. 18. Л. 6ооб.-61).

С 11 по 14 декабря истребительно-диверсионный отряд 255 морской стрелковой бригады 56 армии в количестве 18 человек под командой младшего лейтенанта Росляка действовал в районе Трех Дубов. Отрядом уничтожено 4 офицера и до 50 солдат войск гитлеровской коалиции, 28 лошадей, 2 вьючных обоза с боеприпасами (ЦАМО. Ф. 276. Оп. 811. Д. 134. Л. 1).

Армейский истребительно-диверсионный отряд № 2 в количестве 24 человек под командой младшего лейтенанта Родионова с 18 по 21 декабря действовал в районе дороги 5 км северо-западнее Смоленской. Отряд заминировал участок дороги, на котором подорвалась подвода с 4 немецкими солдатами. Также была обстреляна группа автоматчиков, из которых 10 человек было убито и ранено (ЦАМО. Ф. 276. Оп. 811. Д. 134. Л. 2).

Истребительно-диверсионный отряд 68 морской стрелковой бригады 56 армии с 27 по 31 декабря действовал в немецком тылу в районе 1 км юго-западнее Красного Аула. В результате боевых действий отряда уничтожены 1 автомашина с 18 солдатами и 2 автомашины с боеприпасами, добыты разведывательные данные в районах выс. 620.8 и Красный Аул (ЦАМО. Ф. 276. ОП. 811. Д. 134. Л. 1).

В декабре 1942 г. в частях и соединениях 56 армии действовали 9 истребительнодиверсионных отрядов, из них 2 армейских и 7 отрядов соединений и частей армии, которые совершили 18 выходов в тыл войск вермахта. Боевые действия в немецком тылу провели только 4 группы, остальные вернулись без результатов вследствие невозможности проникнуть через укрепленный передний край обороны войск вермахта. В декабре истребительно-диверсионные отряды 395 стрелковой дивизии не действовали ввиду малочисленности боевого состава подразделений и проводившегося противником наступления на фронте дивизии (ЦАМО. Ф. 276. Оп. 811. Д. 134. Л. 10б.-2).

В конце декабря 1942 г. в 56 армии дополнительно были сформированы два армейских истребительно-диверсионных отряда - № 3 в количестве 39 человек под командой гвардии старшего лейтенанта Макарова и № 4 в составе 38 человек под командой гвардии лейтенанта Ерохомовича (ЦАМО. Ф. 276. Оп. 811. Д. 134. Л. 2-2об.).

Следует отметить, что во второй половине декабря 1942 г. командованием войск вермахта было запланировано отступление с занимаемых позиций на Северном Кавказе. С 17 декабря войска Третьего рейха на участке обороны 18 армии начали отходить с г. Семашхо на правый берег р. Пшиш, минируя позиции. С 22 декабря на линии своей обороны немцы принялись укреплять высоты, гребни, а стыки между ними минировать и 
устанавливать проволочные заграждения, что затрудняло доступ истребительнодиверсионных отрядов в тыл войск вермахта (ЦАМО. Ф. 371. Оп. 6367. Д. 102. Л. 187, 190).

1 января 1943 г. истребительно-диверсионный отряд 723 стрелкового полка 395 стрелковой дивизии 56 армии, действовавший в районе урочища Русская щель и выс. 403.3, обнаружил, что подходы к дорогам заминированы и охраняются патрулями с собаками (ЦАМО. Ф. 1721. Оп. 1. Д. 16. Л. 3).

6 января 1943 г. армейским истребительно-диверсионным отрядом 56 армии в районе выс. 408.0 4 км юго-восточней Ставропольской захвачен в плен унтер-офицер, принадлежавший 4 эскадрону 13 кавалерийского полка 9 кавалерийской дивизии румын (ЦАМО. Ф. 412. Оп. 10282. Д. 96. Л. 4об.).

Действующий в тылу противника в районе дороги Ново-Алексеевский - Свободный армейский истребительно-диверсионный отряд № 5 в ночь на 17 января 1943 г. разгромил немецкий обоз. Было уничтожено до 20 солдат, захвачено 40 лошадей с повозками и 3 пленных, принадлежавших 97 егерской дивизии (ЦАМО. Ф. 412. Оп. 10282. Д. 96. Л. 11).

Армейский истребительно-диверсионный отряд 56 армии под командованием Смирнова, действовавший в ночь на 26 января 1943 г. в районе 6 км южнее Прицепиловки, уничтожил 30 автомашин, 15 подвод и до 70 солдат войск гитлеровской коалиции, взял в плен расчет батареи 1 моторизованной дивизии словаков. Трофеи: 15 лошадей, 2 станковых пулемета (ЦАМО. Ф. 412. Оп. 10282. Д. 96. Л. 200б.).

Спад боевой активности истребительно-диверсионных отрядов происходит в декабре 1942 г. - январе 1943 г., т.к. войска вермахта в преддверии наметившегося отступления создали широко развитую систему инженерных заграждений (минные поля и проволочные заграждения). Ухудшение метеорологических условий также негативно отразились на боевой активности истребительно-диверсионных отрядов. Снежный покров местами достигал 2 м. Следует отметить, что при наступлении потери 18 армии за 25 января 1943 г. составили 30 человек, преимущественно подорвавшихся на минах (ЦАМО. Ф. 371. Оп. 6367. Д. 217. Л. 9, 16).

В связи с переходом в наступление частей и соединений Черноморской группы войск в феврале и марте 1943 г. истребительно-диверсионные отряды не были задействованы. На основании директивы Ставки Верховного Главнокомандования № 30037 от 4 февраля 1943 г. Черноморская группа войск Закавказского фронта с 24 час. оо мин. 5 февраля 1943 г. в существующем виде передана в состав Северо-Кавказского фронта (ЦАМО. Ф. 276. Оп. 811. Д. 215. Л. 27).

На основании приказа № о14/ОП от 16 марта 1943 г. Ставки Верховного Главнокомандования управление и штаб Черноморской группы войск были расформированы, а войска группы перешли в непосредственное подчинение СевероКавказского фронта (ЦАМО. Ф. 276. Оп. 811. Д. 216. Л. 73-74).

При подсчете количества уничтоженной живой силы и техники, взятых трофеев и собственных потерь следует учесть, что обе противоборствующие стороны систематически завышали потери противника и, соответственно, занижали свои. Поэтому полагаем, что итоги деятельности истребительно-диверсионных отрядов (с учетом трех рейдов в немецкий тыл в августе 1942 г. отрядов Северо-Кавказского фронта) в период с августа 1942 г. по январь 1943 г. являются приблизительными. В указанный период истребительнодиверсионными отрядами Черноморской группы войск было ликвидировано около 2500 и ранено 115 солдат и офицеров войск вермахта, уничтожено 165 лошадей и 7 горных мулов. Из вооружения было уничтожено 1 орудие, 1 станковый пулемет, 9 дзотов, 3 пулемета, 47 винтовок, 2 склада с боеприпасами, большое количество транспортных средств: 81 автомашина, 3 бронемашины, 2 вездехода, 2 тягача, 14 мотоциклов, 112 повозок с грузом. Повреждены 2 радиостанции, 2 телефонных аппарата, 46 линий телефонной связи, 1 линия телеграфной связи, километры кабеля, а также тонны продовольствия и фуража. Взорван мост, бензобак и 2 кухни.

Истребительно-диверсионными отрядами было захвачено 32 солдата и офицера войск Третьего рейха, 76 лошадей, 4 миномета, 16 пулеметов, 12 дисков к пулеметам, 2 противотанковых ружья, 32 автомата, 158 винтовок, 12 пистолетов, 250 мин, 110 ручных гранат и ящик патронов. Трофеи транспортных средств составили 1 мотоцикл, 12 повозок с боеприпасами и 14 повозок с продовольствием. Кроме этого, захвачены 1 бинокль, 
3 противогаза, 3 радиостанции, 1 рация, 1 телефонный аппарат, 5 км кабеля связи, 1 буссоль, 1 фотоаппарат, а также большое количество обмундирования и ценных документов и разведывательных данных.

Потери истребительных отрядов составили: около 20 человек убитых и более 10 человек раненых, пропало без вести 12 бойцов, дезертировало 6 человек.

\section{5. Заключение}

Таким образом, в первой половине августа 1942 г. командованием Северо-Кавказского фронта были разработаны приказы и директивы, в соответствие с которыми войска фронта активными боевыми действиями в немецком тылу должны были проводить диверсионные акции, направленные на уничтожение живой силы и техники войск гитлеровской коалиции. Во второй половине августа 1942 г. созданные истребительно-диверсионные отряды в 12 и 56 армиях произвели в немецком тылу несколько удачных боевых операций.

В начале сентября 1942 г. Северо-Кавказский фронт был преобразован в Черноморскую группу войск Закавказского фронта, в которой продолжалось создание истребительнодиверсионных отрядов. Активными боевыми действиями истребительно-диверсионных отрядов Черноморской группы войск в немецком тылу в течение сентября 1942 г. - января 1943 г. войскам вермахта были нанесены значительные потери в живой силе и технике.

Действиями отрядов был затруднен подвоз боеприпасов и продовольствия из немецкого тыла на передовые позиции войск вермахта. Солдаты и офицеры войск гитлеровской коалиции из-за боевых действий истребительно-диверсионных отрядов находились в постоянном напряжении, полагая, что в их тылу действуют группы партизан.

Для охраны своего тыла и борьбы с истребительно-диверсионными отрядами командование войск вермахта приступило к созданию из населения Краснодарского края казачьих сотен, а также использовало подразделения, составленные из представителей различных национальностей Советского Союза из числа пленных офицеров и солдат РККА.

Кроме этого, истребительно-диверсионные отряды в период своей деятельности захватили большое количество ценных документов и сведений о группировке войск вермахта, действующих перед фронтом Черноморской группы войск.

\section{Литература}

Баданин, 1962 - Баданин Б.В. На боевых рубежах Кавказа. Очерки по инженерному обеспечению битвы за Кавказ в Великой Отечественной войне. М., 1962.

Битва за Кавказ, 2002 - Битва за Кавказ (1942-1943 гг.). Редакционный совет А.С. Дзасохов, А.В. Квашнин. М., 2002.

Бормотов, 2009 - Бормотов И.В. В боях под Майкопом. Майкоп, 2009.

Великая Отечественная..., 2020 - Великая Отечественная война в истории и памяти народов Юга России: события, участники, символы: Материалы Всероссийской научной конференции, посвященной 75-летию Победы в Великой Отечественной войне (г. Ростов-наДону, 10-11 сентября 2020 г.) // Отв. ред. акад. Г.Г. Матишов. Ростов-на-Дону, 2020.

Гречко, 1967 - Гречко А.А. Битва за Кавказ. М., 1967.

Гречко, 1969 - Гречко А.А. Битва за Кавказ. Издание второе, дополненное. М., 1969.

Гуцалов, 2005 - Гуцалов А.A. Бои за Оплепен и их значение в битве за Кавказ (19421943) // Наследие веков. 2005. № 1.

Дегрелль, 2012 - Дегрелль Леон. Эссесовский легион Гитлера. Откровения с петлей на шеe. М., 2012.

Дегрелль, 2013 - Дегрелль Леон. Любимец Гитлера: Русская кампания глазами генерала СС. М., 2013.

Дегрелль, 2018 - Дегрелль Леон. Вторая мировая война: взгляд европейца. М., 2018.

Завьялов, Калядин, 1957 - Завьялов А.С., Калядин Т.Е. Битва за Кавказ 1942-1943 гг. M., 1957.

Киселев, 2017а - Киселев И.В. Испытание войной. Краснодарский край в 19411945 годах // Наследие веков. 2017. № 4.

Киселев, 2017b - Киселев И.В. Совместные операции армии и Черноморского флота в ходе битвы за Кавказ (1942-1943 гг.). Краснодар, 2017. 
Киселев, 2020 - Киселев И.В. Веди, Буденный, диверсантов в бой! // Родина. 2020. № 7. C. 126-129.

Коллаборационизм..., 2003 - Коллаборационизм на территории Краснодарского края в период немецкой оккупации (1942-1943 гг.): Малоизвестные страницы // Сборник документов. Авт. предисл. и авт.-сост. А.А. Черкасов. Сочи, 2003.

Конрад, 1954 - Конрад Рудоль . Битва за Кавказ. Мюнхен, 1954.

Кубань..., 1965 - Кубань в Великой Отечественной войне 1941-1945 гг. Сборник документов и материалов. Краснодар, 1965.

Кубань..., 2000 - Кубань в годы Великой Отечественной войны 1941-1945 гг. Хроника событий. Книга первая 1941-1942 гг. / Отв. составители А.М. Беляев, И.Ю. Бондарь. Краснодар, 2000.

Манштейн, 2012 - Манштейн Эрих. Битва за Кавказ. Неизвестная война на море и на суше. М., 2012.

Мирзонов, 2020 - Мирзонов А.Р. Битва за перевалы. Другой взгляд. Коломна, 2020.

Основные..., 1986 - Основные административно-территориальные преобразования на Кубани (1793-1985 гг.) // Сост. А.С. Азаренков, И.Ю. Бондарь, Н.С. Вертышева. Краснодар, 1986.

Пятигорский, 1992 - Пятигорский Э.И. История - это то, что было... 1942. Туапсинская оборонительная операция. Хроника. Факты. Размышления, комментарии и версии краеведа. Туапсе, 1992.

Тике, 2005 - Тике Вильгельм. Марш на Кавказ. Битва за нефть 1942-1943 гг. М., 2005.

Тике, 2015 - Тике Вильгельм. Батальон «Нордост» в боях за Кавказ: финские добровольцы на Восточном фронте, 1941-1943. М., 2015.

Тюленев, 1975 - Тюленев И.В. Крах операции «Эдельвейс». Орджоникидзе, 1975.

Тюленев, 2007 - Тюленев И.В. Через три войны. Воспоминания командующего Южным и Закавказским фронтами. 1941-1945. М., 2007.

Феоктистов, 1995 - Феоктистов С.И. В небе Туапсе: авиация в туапсинской оборонительной операции. Туапсе, 1995.

ЦАМО - Центральный архив Министерства обороны Российской Федерации.

Черкасов, 2008 - Черкасов A.A. Войны в горах: страницы истории обороны города Сочи (1942-1943 гг.). Сочи, 2008.

Эрнстхаузен, 2012 - Эрнстхаузен Адоль командира артиллерийского дивизиона горных егерей. 1942-1943 гг. М., 2012.

Taran, 2020 - Taran K.V. The Military Operations on the Sochi and Lazarev Directions (August 1942) // Voennyi Sbornik. 2020. 8(2): 65-75.

Taran, 2021a - Taran K.V. Military Operations in the North Caucasus in October December 1942 (on the Example of the Lazarev Group of Red Army Troops) // Voennyi Sbornik. 2021. 9(1): 51-66.

Taran, 2021b - Taran K.V. Influence of German Propaganda on the Combat Effectiveness of Soviet Units in 1942 (as illustrated by the 408th Rifle Division) // Propaganda in the World and Local Conflicts. 2021. 8(1): 23-31.

Tyumentsev, 2015 - Tyumentsev I.O. Memories by the Chief of the Neftegorsky Group Staff of Kuban Guerrilla Troops F.S. Gotvan about the Battle at Mount Gunay on September 25, 1942 // Russkii Arkhiv. 2015. 10(4): 296-309.

Tyumentsev, 2016 - Tyumentsev I.O. Documents and Memories by the Commander of the Apsheron Partisan Detachment of Neftegorsk Formation of Partisan Detachments, Sergey S. Zhukov // Russkii Arkhiv. 2016. 13(3): 232-265.

\section{References}

Badanin, 1962 - Badanin, B.V. (1962). Na boevykh rubezhakh Kavkaza. Ocherki po inzhenernomu obespecheniyu bitvy za Kavkaz v Velikoi Otechestvennoi voine [On the combat lines of the Caucasus. Essays on engineering support of the battle for the Caucasus in the Great Patriotic War]. M. [in Russian]

Bitva za Kavkaz, 2002 - Bitva za Kavkaz (1942-1943 gg.) [Battle for the Caucasus (19421943)]. Redaktsionnyi sovet A.S. Dzasokhov, A.V. Kvashnin. M., 2002. [in Russian] 
Bormotov, 2009 - Bormotov, I.V. (2009). V boyakh pod Maikopom [In the battles near Maykop]. Maikop. [in Russian]

Cherkasov, 2008 - Cherkasov, A.A. (2008). Voiny v gorakh: stranitsy istorii oborony goroda Sochi (1942-1943 gg.) [Wars in the mountains: pages of the history of the defense of the city of Sochi (1942-1943)]. Sochi. [in Russian]

Degrell', 2012 - Degrell', L. (2012). Essesovskii legion Gitlera. Otkroveniya s petlei na shee [Hitler's Legion of Esseses. Revelations with a noose around the neck]. M. [in Russian]

Degrell', 2013 - Degrell', L. (2013). Lyubimets Gitlera: Russkaya kampaniya glazami generala SS [Hitler's Favorite: The Russian Campaign Through the Eyes of an SS General.]. M. [in Russian]

Degrell', 2018 - Degrell', L. (2018). Vtoraya mirovaya voina: vzglyad evropeitsa [World War II: A European View]. M. [in Russian]

Ernstkhauzen, 2012 - Ernstkhauzen, A. (2012). Voina na Kavkaze. Perelom. Memuary komandira artilleriiskogo diviziona gornykh egerei. 1942-1943 gg. [War in the Caucasus. Fracture. Memoirs of the commander of the artillery battalion of mountain rangers]. M. [in Russian]

Feoktistov, 1995 - Feoktistov, S.I. (1995). V nebe Tuapse: aviatsiya v tuapsinskoi oboronitel'noi operatsii [In the skies of Tuapse: aviation in the Tuapse defensive operation]. Tuapse. [in Russian]

Grechko, 1967 - Grechko, A.A. (1967). Bitva za Kavkaz [Battle for the Caucasus]. M. [in Russian]

Grechko, 1969 - Grechko, A.A. (1969). Bitva za Kavkaz [Battle for the Caucasus]. Izdanie vtoroe, dopolnennoe. M. [in Russian]

Gutsalov, 2005 - Gutsalov, A.A. (2005). Boi za Oplepen i ikh znachenie v bitve za Kavkaz (1942-1943) [The battles for Oplepen and their significance in the battle for the Caucasus (1942-1943)]. Nasledie vekov. 1. [in Russian]

Kiselev, 2017a - Kiselev, I.V. (2017). Ispytanie voinoi. Krasnodarskii krai v 19411945 godakh [Trial by war. Krasnodar Kray in 1941-1945]. Nasledie vekov. 4. [in Russian]

Kiselev, 2017b - Kiselev, I.V. (2017). Sovmestnye operatsii armii i Chernomorskogo flota v khode bitvy za Kavkaz (1942-1943 gg.) [Joint operations of the army and the Black Sea Fleet during the Battle of the Caucasus (1942-1943)]. Krasnodar. [in Russian]

Kiselev, 2020 - Kiselev, I.V. (2020). Vedi, Budennyi, diversantov v boi! [Lead the saboteurs into battle, Budyonny!]. Rodina. 7: 126-129. [in Russian]

Kollaboratsionizm..., 2003 - Kollaboratsionizm na territorii Krasnodarskogo kraya v period nemetskoi okkupatsii (1942-1943 gg.): Maloizvestnye stranitsy [Collaboration on the territory of the Krasnodar Territory during the German occupation (1942-1943): Little-known pages]. Sbornik dokumentov. Avt. predisl. i avt.-sost. A.A. Cherkasov. Sochi, 2003. [in Russian]

Konrad, 1954 - Konrad, R. (1954). Bitva za Kavkaz [Battle for the Caucasus]. Myunkhen. [in Russian]

Kuban'..., 1965 - Kuban' v Velikoi Otechestvennoi voine 1941-1945 gg. [Kuban in the Great Patriotic War of 1941-1945]. Sbornik dokumentov i materialov. Krasnodar, 1965. [in Russian]

Kuban'..., 2000 - Kuban' v gody Velikoi Otechestvennoi voiny 1941-1945 gg. Khronika sobytii. Kniga pervaya 1941-1942 gg. [Kuban during the Great Patriotic War of 1941-1945. Chronicle of events. The first book, 1941-1942]. Otv. sostaviteli A.M. Belyaev, I.Yu. Bondar'. Krasnodar, 2000. [in Russian]

Manshtein, 2012 - Manshtein, E. (2012). Bitva za Kavkaz. Neizvestnaya voina na more i na sushi [attle for the Caucasus. Unknown war at sea and on land.]. M. [in Russian]

Mirzonov, 2020 - Mirzonov, A.R. (2020). Bitva za perevaly. Drugoi vzglyad [Battle for the passes. Another look]. Kolomna. [in Russian]

Osnovnye..., 1986 - Osnovnye administrativno-territorial'nye preobrazovaniya na Kubani (1793-1985 gg.) [Basic administrative and territorial transformations in the Kuban (1793-1985)]. Sost. A.S. Azarenkov, I.Yu. Bondar', N.S. Vertysheva. Krasnodar, 1986. [in Russian]

Pyatigorskii, 1992 - Pyatigorskii, E.I. (1992). Istoriya - eto to, chto bylo... 1942. Tuapsinskaya oboronitel'naya operatsiya. Khronika. Fakty. Razmyshleniya, kommentarii i versii kraeveda [History is what it was ... 1942. Tuapse defensive operation. Chronicle. Facts. Reflections, comments and versions of a local historian.]. Tuapse. [in Russian] 
Taran, 2020 - Taran, K.V. (2020). The Military Operations on the Sochi and Lazarev Directions (August 1942). Voennyi Sbornik. 8(2): 65-75.

Taran, 2021a - Taran, K.V. (2021). Military Operations in the North Caucasus in October December 1942 (on the Example of the Lazarev Group of Red Army Troops). Voennyi Sbornik. 9(1): 51-66.

Taran, 2021b - Taran, K.V. (2021). Influence of German Propaganda on the Combat Effectiveness of Soviet Units in 1942 (as illustrated by the 408th Rifle Division). Propaganda in the World and Local Conflicts. 8(1): 23-31.

Tike, 2005 - Tike, V. (2005). Marsh na Kavkaz. Bitva za neft' 1942-1943 gg. [March to the Caucasus. Battle for Oil 1942-1943]. M. [in Russian]

Tike, 2015 - Tike, V. (2015). Batal'on «Nordost» v boyakh za Kavkaz: finskie dobrovol'tsy na Vostochnom fronte, 1941-1943 [The battalion "Nordost" in the battles for the Caucasus: Finnish volunteers on the Eastern Front, 1941-1943]. M. [in Russian]

TsAMO - Tsentral'nyi arkhiv Ministerstva oborony Rossiiskoi Federatsii [Central archive of the Ministry of Defense of the Russian Federation].

Tyulenev, 1975 - Tyulenev, I.V. (1975). Krakh operatsii «Edel'veis» [The collapse of "Edelweiss" operation]. Ordzhonikidze. [in Russian]

Tyulenev, 2007 - Tyulenev, I.V. (2007). Cherez tri voiny. Vospominaniya komanduyushchego Yuzhnym i Zakavkazskim frontami. 1941-1945 [After three wars. Memoirs of the commander of the Southern and Transcaucasian fronts. 1941-1945.]. M. [in Russian]

Tyumentsev, 2015 - Tyumentsev, I.O. (2015). Memories by the Chief of the Neftegorsky Group Staff of Kuban Guerrilla Troops F.S. Gotvan about the Battle at Mount Gunay on September 25, 1942. Russkii Arkhiv. 10(4): 296-309.

Tyumentsev, 2016 - Tyumentsev, I.O. (2016). Documents and Memories by the Commander of the Apsheron Partisan Detachment of Neftegorsk Formation of Partisan Detachments, Sergey S. Zhukov. Russkii Arkhiv. 13(3): 232-265.

Velikaya Otechestvennaya..., 2020 - Velikaya Otechestvennaya voina v istorii i pamyati narodov Yuga Rossii: sobytiya, uchastniki, simvoly: Materialy Vserossiiskoi nauchnoi konferentsii, posvyashchennoi 75-letiyu Pobedy v Velikoi Otechestvennoi voine (g. Rostov-na-Donu, 10-11 sentyabrya 2020 g.) [The Great Patriotic War in the history and memory of the peoples of the South of Russia: events, participants, symbols: Materials of the All-Russian scientific conference dedicated to the 75th anniversary of Victory in the Great Patriotic War (Rostov-on-Don, September 10-11 2020)]. Otv. red. akad. G.G. Matishov. Rostov-na-Donu, 2020. [in Russian]

Zav'yalov, Kalyadin, 1957 - Zav'yalov, A.S., Kalyadin, T.E. (1957). Bitva za Kavkaz 19421943 gg. [Battle for the Caucasus 1942-1943]. M. [in Russian]

\title{
Создание и боевые действия истребительно-диверсионных отрядов Черноморской группы войск в годы Второй мировой войны
}

\author{
Константин Викторович Таран ${ }^{\mathrm{a}, \mathrm{b}, \text { * }}$ \\ а Черкас глобальный университет, Вашингтон, США \\ b Волгоградский государственный университет, Волгоград, Российская Федерация
}

Аннотация. В данной статье рассматриваются создание и боевая деятельность истребительно-диверсионных отрядов Черноморской группы войск Закавказского фронта, целью которых было уничтожение живой силы и техники войск гитлеровской коалиции. Кроме этого, действуя в тылу войск Третьего рейха, истребительно-диверсионные отряды добывали ценные разведывательные данные.

В качестве источников были использованы материалы Центрального архива Министерства обороны Российской Федерации (Подольск, Российская Федерация), такие как итоговые оперативные сводки, журналы боевых действий, боевые донесения, справки,

\footnotetext{
* Корреспондирующий автор

Адреса электронной почты: taran.constantin@yandex.ru (К.В. Таран)
} 
отчеты, доклады и т.д. Дополнительно были задействованы сборники архивных документов и материалов, а также исследования советских, российских и зарубежных авторов.

В заключении автор указывает, что в результате боевых действий истребительнодиверсионных отрядов были нанесены значительные потери живой силе и технике войскам Третьего рейха, а также захвачены ценные документы разведывательного характера.

Ключевые слова: Вторая мировая война, Северо-Кавказский фронт, истребительнодиверсионные отряды, Черноморская группа войск, Закавказский фронт. 